OECD Environment Working Papers No. 41

\title{
An Economic Projection to 2050: The OECD "ENV- Linkages" Model Baseline
}

Cuauhtemoc Rebolledo, Rob Dellink 


\section{Unclassified}

Organisation de Coopération et de Développement Économiques

Organisation for Economic Co-operation and Development

ENVIRONMENT DIRECTORATE
ENV/WKP(2011)11

15-Dec-2011

English - Or. English

OECD ENVIRONMENT WORKING PAPER No. 41

THE ENV-LINKAGES ECONOMIC BASELINE PROJECTIONS TO 2050

By Jean Chateau, Cuauhtemoc Rebolledo and Rob Dellink, OECD Environment Directorate

Keywords: General equilibrium model, climate change, long-term scenarios

JEL Classification: D58, H23, O54, Q56

All Environment Working Papers can be found at www.oecd.org/env/workingpapers

JT03313481

Document complet disponible sur OLIS dans son format d'origine

Complete document available on OLIS in its original format 


\section{OECD ENVIRONMENT WORKING PAPERS}

This series is designed to make available to a wider readership selected studies on environmental issues prepared for use within the OECD. Authorship is usually collective, but principal authors are named.

The papers are generally available only in their original language English or French with a summary in the other if available.

The opinions expressed in these papers are the sole responsibility of the author(s) and do not necessarily reflect those of the OECD or the governments of its member countries.

Comment on the series is welcome, and should be sent to either env.contact@oecd.org or the Environment Directorate, 2 rue André Pascal, 75775 PARIS CEDEX 16, France.

OECD Environment Working Papers are published on www.oecd.org/env/workingpapers

Applications for permission to reproduce or translate all or part of this material should be made to: OECD Publishing, rights@oecd.org or by fax 33145249930.

Copyright OECD 2011 
ENV/WKP(2011)11

\begin{abstract}
This document describes economic baseline projections to 2050 for several world regions. It describes how socio-economic drivers are used to create a consistent projection of economic activity for the coming decades, applying the general framework of "conditional convergence". This economic baseline is created using the ENV-Linkages model version 3. This baseline is used for modelling analysis with the ENVLinkages model as carried out for the OECD Environmental Outlook to 2050 (to be released in Spring 2012). Specific attention is given in this paper to projections for the energy system as part of the economy, to allow detailed links between economic activity and environmental pressures, including emissions of greenhouse gases (GHGs).
\end{abstract}

Keywords: General equilibrium model, climate change, long-term scenarios

JEL Classification: D58, H23, O41, Q54, Q56

\title{
RÉSUMÉ
}

Ce document décrit les projections économiques mondiales d'un scénario de référence à l'horizon 2050. Il explique comment les différents déterminants socio-économiques sont combinés entre eux pour créer une projection cohérente de l'activité économique pour les décennies à venir, sur la base d'un cadre d'analyse fondé sur la « convergence conditionnelle». Ce scénario économique de référence est obtenu au moyen de simulations du modèle ENV-linkages (version 3). Ce compte central est utilisé comme point de référence des exercices de simulations numériques proposées dans les « Perspective de l'Environnement de l'OCDE à l'horizon 2050 » (à paraître au printemps 2012). Une attention particulière aux projections énergétiques est entreprise, dans la mesure où celles-ci sont des éléments centraux de l'interaction entre activité économique et pression sur l'environnement, au travers notamment des émissions de gaz à effets de serre.

Mots-clés: Modèle d'équilibre général calculable, changement climatique, scénarios de long-terme

Classification JEL: D58, H23, O41, Q54, Q56 


\section{FOREWORD}

This report presents global socioeconomic baseline projections until 2050. It highlights how different drivers affect growth in GDP, and how this in turn affects energy use and greenhouse gas emissions. The Baseline scenario documented here serves as a background document for the preparation of the Socioeconomic Developments chapter of the OECD Environmental Outlook to 2050. The baseline has been constructed using the ENV-Linkages model, which is described in detail in a separate paper of the OECD Environment Working Paper series.

This report has been authored by Jean Chateau, Cuauhtemoc Rebolledo and Rob Dellink of the OECD Environment Directorate. It was reviewed by delegates of the Environmental Policy Committee as part of the review process for the Environmental Outlook to 2050. The authors are also grateful to Jean-Marc Burniaux, Elisa Lanzi and Bertrand Magne of the OECD for valuable comments and inputs.

This document does not necessarily represent the view of either the OECD or its member countries. It is published under the responsibility of the Secretary General.

More information on these baseline projections and on the ENV-Linkages model can be found at www.oecd.org/environment/modelling. Further enquiries should be directed to Rob Dellink or Jean Chateau at the OECD Environment Directorate (email rob.dellink@oecd.org, tel. +33 14524 1953; and email jean.chateau@oecd.org, tel. +33 14524 9305). 


\section{TABLE OF CONTENTS}

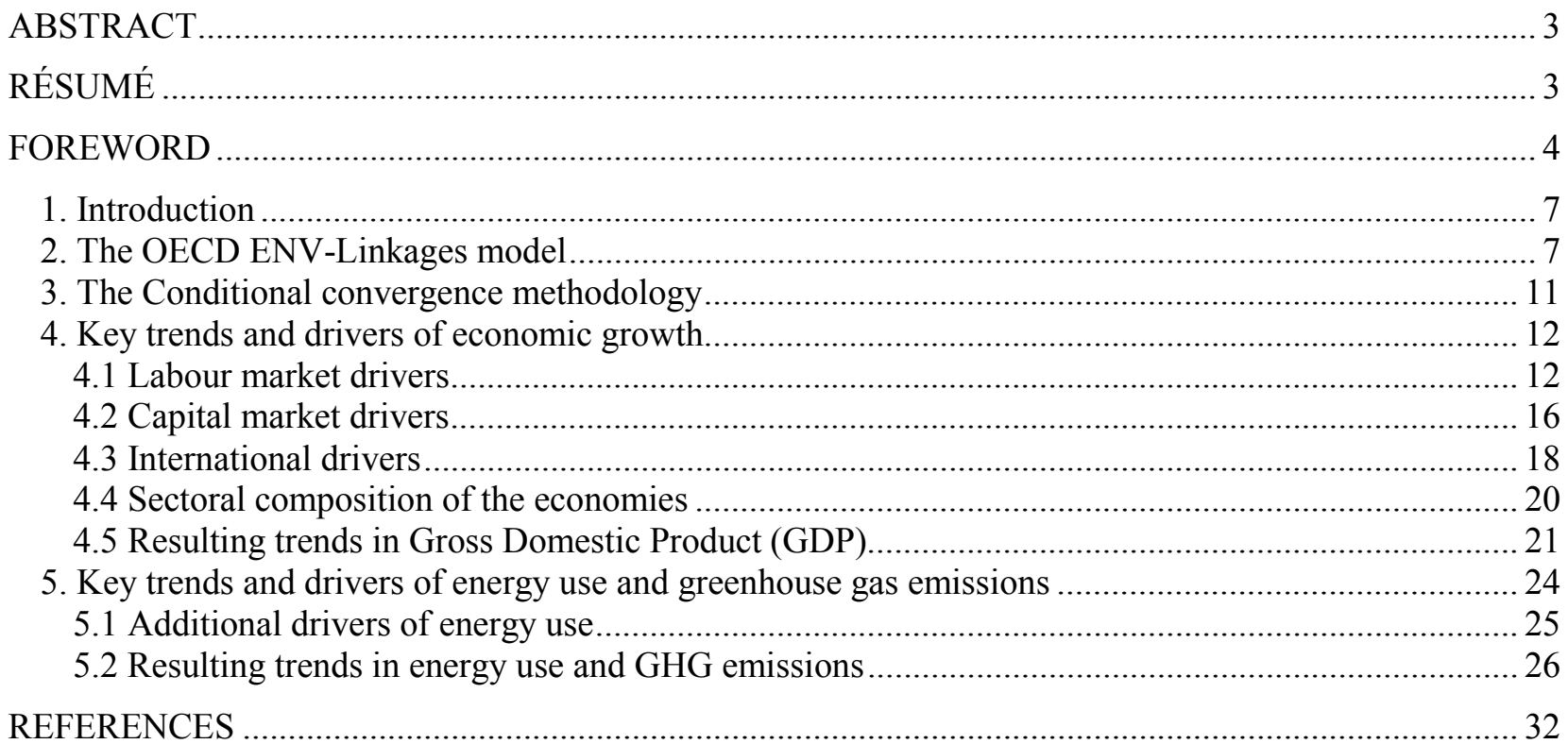

ANNEX. STYLISED REPRESENTATION OF THE GENERIC PRODUCTION FUNCTION IN ENV-

\section{List of Tables}

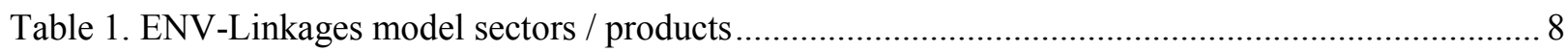

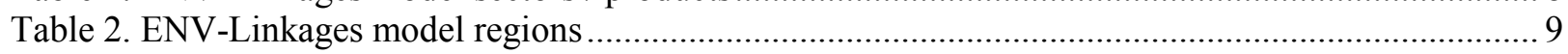

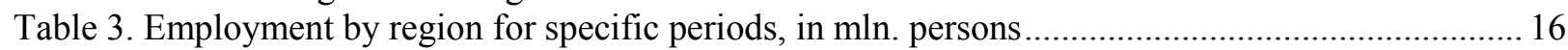

Table 4. Annual average real GDP growth rates, 2010-2050 Based on constant 2010 USD PPP ........... 22

\section{List of Figures}

Figure 1. Trend in population by region, mln. persons

Figure 2. Average annual growth rates of population and employment for the period 2010-2050, in percentage......

Figure 3. Decomposition of the drivers of employment changes by region, in percentage ..................... 14

Figure 4. Trend in gross capital investments by region, in percentage of GDP ....................................... 17

Figure 5. Trend in public savings by region, in percentage of GDP ............................................... 17

Figure 6. Trend in private savings by region, in percentage of household disposable income ................. 18

Figure 7. Trend in current account balances by region, in 2010 constant billions USD at MER............. 19

Figure 8. Trend in real exchange rates by region, indexed to 2010 .................................................. 19

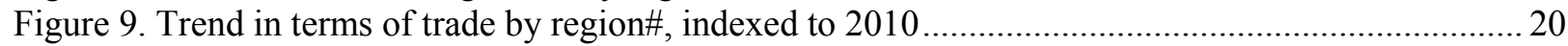


Figure 10. Sectoral composition of GDP by region for specific periods, in percentage ......................... 20 Figure 11. Trend in real Gross Domestic Product (GDP) valued at market prices by region, in billions

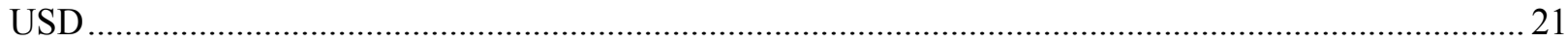

Figure 12. Decomposition of the drivers of GDP growth by region, in percentage................................23

Figure 13. Per capita household consumption by region for specific periods, relative to USA................ 24



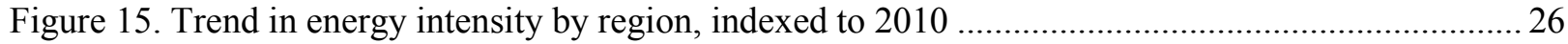

Figure 16. Production of fossil fuels and non-fossil fuel based electricity, by region, in Mtoe................27

Figure 17. Global electricity generation by source of energy, 2010, 2030 and 2050 (in GWh) .............28

Figure 18. Decomposition of the drivers of energy use growth by region, in percentage........................29

Figure 19. Trend in emissions of greenhouse gases, in MtCO2e .......................................................... 30

Figure 20. Comparison of global emissions of $\mathrm{CO} 2$ from fossil fuel combustion across with other

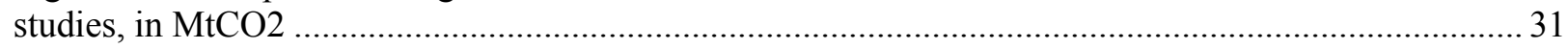


ENV/WKP(2011)11

\section{Introduction}

A baseline projection describes a possible future development and is not a prediction of future developments. Rather, it provides an internally consistent set of trend developments of all economic and environmental variables of the model. The baseline projection is calibrated such that it reproduces expected future trends for several key economic and environmental variables that are derived from published sources, including the IEA, UN and OECD. The baseline assumes no new environmental policies, but implicitly includes other government policies that are included in the expected trends for the key variables (see Sections 2 and 3 for more details). It thus provides a benchmark against which policy scenarios aimed at improving environmental quality for the issues under investigation can be assessed. One robust way to portray modelling results consists in expressing the impact of policy changes on the model variables in terms of changes relative to a baseline, rather than providing absolute numbers.

The structure of this document is as follows. The next two sections provide background information on the ENV-Linkages model and the "conditional convergence" methodology, respectively. Then, in Section 4 the socio-economic drivers of economic growth are described, and the resulting macroeconomic trend is presented. Section 5 describes additional drivers that influence the energy system over the model horizon, and the resulting projected baseline trends for energy use and GHG emissions.

\section{The OECD ENV-Linkages model}

The OECD's ENV-Linkages general equilibrium (GE) model is an economic model that describes how economic activities are linked to each other across sectors and regions. It also links economic activity to environmental pressures, specifically to emissions of greenhouse gases (GHGs). The model projects these links between economic activities and emissions several decades into the future to shed light on the medium- and long-term impacts of environmental policies. The advantages of multi-sectoral, multiregional dynamic GE models like ENV-Linkages are several, and include their global dimension, their overall consistency and the fact that they build on rigorous micro-economic foundations. These models are best suited for analysing the medium- and long-term implications of large policy shifts requiring significant reallocation across sectors and countries/regions, as well as the associated spill-over effects. In that sense, these models are the tools of choice for assessing a wide range of climate change policies.

ENV-Linkages is the successor to the OECD GREEN model, initially developed by the OECD's Economics Department (Burniaux, et al. 1992) and is now hosted by the OECD Environment Directorate. Much of the applied work carried out with the model has been reported in various chapters of the OECD Environmental Outlook to 2030 (OECD, 2008). An updated version of the model was used extensively in the joint project between the OECD Economics Department and the OECD Environment Directorate on the economics of climate change mitigation (OECD, 2009). Most recently, the model has been used to study the impacts of phasing out fossil fuels subsidies (IEA, OPEC, OECD, World Bank, 2010; Burniaux and Chateau, 2011); the impacts of border-tax adjustments (Burniaux et al., 2010); direct and indirect linking of carbon markets (Dellink et al., 2010a; and the costs and effectiveness of the Copenhagen pledges (Dellink et al., 2010b). A more detailed overview of the ENV-Linkages version 3, as used for this OECD Environmental Outlook to 2050 (OECD, 2012), is provided in Chateau et al. (2012).

ENV-Linkages is a global economic model built primarily on a database of national economies. In the version of the model used here, the world economy is divided in 15 countries/regions, each with 26 economic sectors (Tables 1 and 2), including seven different technologies to produce electricity. 
ENV/WKP(2011)11

Table 1. ENV-Linkages model sectors / products

\begin{tabular}{|c|c|}
\hline SECTORS & DESCRIPTION \\
\hline \multirow{5}{*}{ Other crops } & Wheat: wheat and meslin \\
\hline & Vegetables and fruits: vegetables, fruits, fruit and nuts, potatoes, cassava, truffles \\
\hline & Oil seeds: oil seeds and oleaginous fruits; soy beans, copra \\
\hline & Cane \& beet: sugar cane and sugar beet \\
\hline & Other crops \\
\hline \multirow{4}{*}{ Livestock } & Cattle: cattle, sheep, goats, horses, asses, mules, and hinnies; and semen thereof \\
\hline & Other animal products: swine, poultry and other live animals; eggs, in shell, natural honey, snails \\
\hline & Raw milk \\
\hline & Wool: wool, silk, and other raw animal materials used in textile \\
\hline Coal & Mining and agglomeration of hard coal, lignite and peat \\
\hline \multirow{2}{*}{ Gas extraction \& distribution } & Parts of extraction of natural gas \& service activities incidental to gas extraction excl. surveying \\
\hline & Distribution of gaseous fuels through mains; steam and hot water supply \\
\hline Electricity & Production, collection and distribution \\
\hline Petroleum \& coal products & Petroleum and coke: coke oven products, refined petroleum products, processing of nuclear fuel \\
\hline \multirow{5}{*}{ Food products } & Cattle meat: fresh or chilled meat and edible offal of cattle, sheep, goats, horses, asses, mules \\
\hline & Other meat: Pig meat and offal. Preserves and preparations of meat, meat offal or blood, flours \\
\hline & Vegetable oils: crude and refined oils of soya-bean, maize, olive, sesame, groundnut, olive seeds \\
\hline & Milk: dairy products \\
\hline & Processed rice: rice, semi- or wholly milled \\
\hline Paper \& paper products & Includes publishing, printing and reproduction of recorded media \\
\hline Non-metallic minerals & Cement, plaster, lime, gravel, concrete \\
\hline \multirow{9}{*}{ Other manufacturing } & Textiles: textiles and man-made fibers \\
\hline & Wearing apparel: clothing, dressing and dyeing of fur \\
\hline & Leather: tanning and dressing of leather; luggage, handbags, saddlery, harness and footwear \\
\hline & Other transport equipment: manufacture of other transport equipment \\
\hline & Electronic equipment: office, accounting and computing, radio, television and communication equipment \\
\hline & Other machinery \& equipment: electrical machinery, medical, precision and optical, watches \\
\hline & Other manufacturing: includes recycling \\
\hline & Motor vehicles: cars, lorries, trailers and semi-trailers \\
\hline & Lumber: wood and products of wood and cork, except furniture; articles of straw and plaiting materials \\
\hline \multirow{3}{*}{ Transport services } & Water transport \\
\hline & Air transport \\
\hline & Other transport: road, rail ; pipelines, auxiliary transport activities; travel agencies \\
\hline
\end{tabular}

Trade: all retail sales; wholesale trade and commission trade; hotels and restaurants; repairs of motor vehicles and personal and household goods Water: collection, purification and distribution

Retail sale of automotive fuel

Communications: post and telecommunications

Services

Other financial intermediation: includes auxiliary activities but not insurance and pension funding

Insurance: includes pension funding, except compulsory social security

Other business services: real estate, renting and business activities

Recreation and other services: recreational, cultural and sporting activities, other service activities; private households with employed persons

Other services (government): public administration and defense; compulsory social security, education, health and social work, sewage and refuse disposal, sanitation and similar activities, activities of membership organizations n.e.c., extra-territorial organizations and bodies

Construction \& dwellings Construction: building houses factories offices and roads

Dwellings: ownership of dwellings (imputed rents of houses occupied by owners) 
ENV/WKP(2011)11

Table 2. ENV-Linkages model regions

\begin{tabular}{|c|c|c|c|}
\hline \multicolumn{3}{|c|}{ Aggregation ENV-Linkages: 15 Regions } & \multirow{2}{*}{ Economies, countries and regions } \\
\hline $\begin{array}{l}\text { Region } \\
\text { number }\end{array}$ & Region ID & Label & \\
\hline 1 & CAN & Canada & Canada, Rest of North America (Bermuda, Greenland, Saint Pierre and Miquelon) \\
\hline \multirow{2}{*}{2} & \multirow{2}{*}{ JPK } & \multirow{2}{*}{ Japan \& Korea } & Japan \\
\hline & & & Korea \\
\hline 3 & OCE & Oceania & $\begin{array}{l}\text { Australia, New Zealand, Rest of Oceania (American Samoa, Cook Islands, Fiji, French Polynesia, Guam, } \\
\text { Kiribati, Marshall Islands, Micronesia, Federated States of, Nauru, New Caledonia, Norfolk Island, Northern } \\
\text { Mariana Islands, Niue, Palau, Papua New Guinea, Samoa, Solomon Islands, Tokelau, Tonga, Tuvalu, } \\
\text { Vanuatu, Island of Wallis and Futuna) }\end{array}$ \\
\hline 4 & RUS & Russia & Russian Federation, Armenia, Azerbaijan, Georgia \\
\hline 5 & USA & USA & Unted States of America \\
\hline \multirow{4}{*}{6} & \multirow{4}{*}{ WEU } & \multirow{4}{*}{$\begin{array}{l}\text { European Union } \\
\text { \& EFTA }\end{array}$} & $\begin{array}{l}\text { Austria , Belgium , Denmark , Finland , France, Germany, Greece , Ireland , Italy, Luxembourg, } \\
\text { Netherlands, Portugal , Spain, Sweden, United Kingdom }\end{array}$ \\
\hline & & & Czech Republic, Estonia, Hungary, Poland, Slovakia, Slovenia \\
\hline & & & Cyprus ${ }^{1,2}$, Latvia , Lithuania , Malta , Bulgaria , Romania \\
\hline & & & Switzerland, Norway, Rest of EFTA (Iceland, Liechtenstein) \\
\hline \multirow{3}{*}{7} & \multirow{3}{*}{ REU } & \multirow{3}{*}{ Rest of Europe } & $\begin{array}{l}\text { Albania, Croatia, Rest of Europe (Andorra, Bosnia and Herzegovina, Faroe Islands, Gibraltar, TFYR } \\
\text { Macedonia, Monaco, San Marino, Serbia and Montenegro) }\end{array}$ \\
\hline & & & Turkey \\
\hline & & & Ukraine, Belarus, Moldova Republic of \\
\hline 8 & BRA & Brazil & Brazil \\
\hline 9 & $\mathrm{CHN}$ & China & $\begin{array}{l}\text { China; Hong Kong, China; Chinese Taipei; Rest of East Asia (Macau, China; Mongolia, Democratic } \\
\text { People's Republic of Korea ) }\end{array}$ \\
\hline 10 & IDN & Indonesia & Indonesia \\
\hline 11 & IND & India & India \\
\hline \multirow[t]{2}{*}{12} & \multirow[t]{2}{*}{ MEA } & \multirow{2}{*}{$\begin{array}{l}\text { Middle East } \\
\& \text { Northern Africa }\end{array}$} & $\begin{array}{l}\text { Islamic Republic of Iran, Rest of Western Asia (Bahrein, Iraq, Israel, Jordan, Kuwait, Lebanon, Oman, } \\
\text { Qatar, Saudi Arabia, Syrian Arab Republic, United Arab Emirates, Yemen) }\end{array}$ \\
\hline & & & Egypt , Morocco , Tunisia , Rest of North Africa (Algeria, Libyan Arab Jamahiriya) \\
\hline 13 & MEX & Mexico & Mexico \\
\hline 14 & ZAF & South Africa & South Africa \\
\hline \multirow{8}{*}{15} & \multirow{8}{*}{ ROW } & \multirow{8}{*}{ Rest of the World } & $\begin{array}{l}\text { Cambodia, Malaysia, Philippines, Singapore, Thailand, Vietnam, Lao People's Democratic Republic, } \\
\text { Rest of Southeast Asia (Brunei Darussalam, Myanmar (MMR), Timor Leste) }\end{array}$ \\
\hline & & & Bangladesh, Pakistan, Sri Lanka, Rest of South Asia (Afghanistan, Bhutan, Maldives, Nepal) \\
\hline & & & Kazakhstan, Kyrgyzstan, Rest of Former Soviet Union (Tajikistan, Turkmenistan, Uzbekistan) \\
\hline & & & $\begin{array}{l}\text { Ethiopia, Madagascar, Mauritius, Uganda, Rest of Eastern Africa (Burundi, Comoros, Djibouti, Eritrea, } \\
\text { Kenya, Mayotte, Reunion, Rwanda, Seychelles, Somalia, Sudan) }\end{array}$ \\
\hline & & & $\begin{array}{l}\text { South-Central Africa (Angola, Congo, the Democratic Republic of the (Zaire)), Malawi, Mozambique, } \\
\text { Tanzania , Zambia , Zimbabwe , Botswana, Rest of South Africa Customs Union (Lesotho, Namibia, } \\
\text { Swaziland) }\end{array}$ \\
\hline & & & $\begin{array}{l}\text { Nigeria, Senegal, Rest of Western Africa (Benin, Burkina Faso, Cape Verde, Cote d'Ivoire, Gambia, } \\
\text { Ghana, Guinea, Guinea-Bissau, Liberia, Mali, Mauritania, Niger, Saint Helena, Sierra Leone, Togo), Central } \\
\text { Africa (Cameroon, Central African Republic, Chad, Congo, Equatorial Guinea, Gabon, Sao Tome and } \\
\text { Principe) }\end{array}$ \\
\hline & & & $\begin{array}{l}\text { Panama, Costa Rica, Guatemala, Nicaragua, Rest of Central America (Belize, El Salvador, Honduras), } \\
\text { Caribbean (Saint Vincent and the Grenadines, Trinidad and Tobago, Turks and Caicos, Anguilla, Antigua } \\
\text { \& Barbuda, Aruba, Bahamas, Barbados, Cayman Islands, Cuba, Dominica, Dominican Republic, } \\
\text { Grenada, Guadeloupe, Haiti, Jamaica, Martinique, Montserrat, Netherlands Antilles, Puerto Rico, Saint Kitts } \\
\text { and Nevis, Saint Lucia, Virgin Islands, British, Virgin Islands, U.S.) }\end{array}$ \\
\hline & & & $\begin{array}{l}\text { Argentina , Bolivia, Chile, Colombia, Ecuador, Paraguay, Peru, Uruguay, Venezuela, Rest of South } \\
\text { America (Falkland Islands (Malvinas), French Guiana, Guyana, Suriname) }\end{array}$ \\
\hline
\end{tabular}

1. Note by Turkey: The information in this document with reference to "Cyprus" relates to the southern part of the Island. There is no single authority representing both Turkish and Greek Cypriot people on the Island. Turkey recognises the Turkish Republic of Northern Cyprus (TRNC). Until a lasting and equitable solution is found within the context of the United Nations, Turkey shall preserve its position concerning the "Cyprus issue".

2. Note by all the European Union Member States of the OECD and the European Commission: The Republic of Cyprus is recognised by all members of the United Nations with the exception of Turkey. The information in this document relates to the area under the effective control of the Government of the Republic of Cyprus. 
The core of the static equilibrium is formed by the set of Social Account Matrices (SAMs) that described how economic sectors are linked; these are based on the GTAP database (GTAP, 2008; version 7.1 is used for this baseline). Many key parameters are set on the basis of information drawn from various empirical studies and data sources (see Chateau et al., 2010).

The ENV-Linkages model has a simple recursive-dynamic structure, where households base their decisions on static expectations concerning prices and quantities. Household consumption, demand and savings are implemented through an "Extended Linear Expenditure System". Since consumers are not represented with forward-looking behaviour, some care needs to be exercised in studying policies that consumers may reasonably be expected to anticipate - either the policy itself or its consequences. In each period, investment net-of-economic depreciation is equal to the sum of government savings, consumer savings and net capital flows from abroad.

World trade is based on a set of regional bilateral flows. Allocation of trade between partners responds to changes in relative prices between regions. The basic assumption is that imports originating from different regions are imperfect substitutes (Armington specification). Each region runs a given stream of current-account surpluses (or deficits).

The government in each region collects various kinds of taxes in order to finance government expenditures. Aggregate government expenditures are linked to real GDP. Assuming a given stream of public savings (or deficits), the government budget is balanced through the adjustment of a lump-sum transfer(tax) to the household.

Production in ENV-Linkages is assumed to operate under cost minimisation with an assumption of perfect markets and constant returns to scale technology. The production technology is specified as nested Constant Elasticity of Substitution (CES) production functions in a branching hierarchy; see the Annex for a stylised representation of this structure. Each sector uses intermediate inputs - including energy inputs and primary factors (labour, capital, land and natural resources). For each good or service, output is produced by different production streams which are differentiated by capital vintage (old and new). The substitution possibilities among production factors are assumed to be higher with the new than with the old capital vintages - technology has a putty/semi-putty specification. Capital accumulation is modelled according to the traditional Solow/Swan neo-classical growth model.

The land-based sectors, including 3 agricultural sectors and forestry, provide direct links to indicators for climate change (e.g. emissions from deforestation), biodiversity (e.g. land under forest cover) and water. The land use module of the ENV-Linkages model is based on information provided by PBL and LEI and calibrated to mimic land use relations in the IMAGE suite of models (Kram et al., 2012). The underlying complexities of the land model in IMAGE, and its detailed links with the agricultural model LEITAP, are approximated in ENV-Linkages in a stylised and aggregated manner where sector-specific transformation elasticities are used to represent land use changes.

The energy bundle is of particular interest for analysis of climate change and health issues related to local air pollution. The composite energy good is a combination of fossil fuels and electricity. In turn, fossil fuel is a composite of coal and a bundle of "other fossil fuels". At the lowest nest, the composite "other fossil fuels" commodity consists of crude oil, refined oil products and gas products. The value of the substitution elasticities are chosen as to imply a higher degree of substitution among the other fuels than with electricity and coal.

$\mathrm{CO}_{2}$ emissions from combustion of energy are directly linked to the use of different fuels in production. Other GHG emissions are linked to output. The following non- $\mathrm{CO}_{2}$ emission sources are considered: i) methane from rice cultivation, livestock production (enteric fermentation and manure 
management), coal mining, crude oil extraction, natural gas and services (landfills); ii) nitrous oxide from crops (nitrogenous fertilizers), livestock (manure management), chemicals (non-combustion industrial processes) and services (landfills); iii) industrial gases ( $\mathrm{SF}_{6}$, PFCs and HFCs) from chemicals industry (foams, adipic acid, solvents), aluminium, magnesium and semi-conductors production. These emissions are calibrated on historical data, as described in IEA(2010b). For non- $\mathrm{CO}_{2}$ GHGs data the IEA relies on the EDGAR 4.1 dataset that PBL developed. For future non- $\mathrm{CO}_{2}$ emissions and for allocation of different sources to activities by the different economic sectors we use information provided by the US-EPA.

Market goods equilibria imply that, on the one side, the total production of any good or service is equal to the demand addressed to domestic producers plus exports; and, on the other side, the total demand is allocated between the demands (both final and intermediary) addressed to domestic producers and the import demand. The general equilibrium framework ensures that a unique set of relative prices emerges such that demand equals supply in all markets simultaneously (i.e. across all regions, commodities, and factors of production). All prices are expressed relatively to the numéraire of the price system that is chosen as the index of OECD manufacturing exports prices. Implementation of a policy in the model leads to a new equilibration process and thus a new set of equilibrium prices and quantities to compare with the original equilibrium.

The process of calibration of the ENV-Linkages model is broken down into three stages (cf. Chateau et al., 2012). First, a number of parameters are calibrated, given some elasticity values, on base-year (2004) values of variables. Second, the 2004 database is updated to 2007 by simulating the model dynamically to match historical trends over this period; thus all monetary variables are expressed in 2007 real USD. Third, the baseline projection to 2050 is based on convergence assumptions as explained in the next section. The baseline has been adjusted to incorporate the effects of the economic crisis of 2008-2009 and latest medium-term projections made by the World Bank (2010), IMF (2010) and OECD (2010). Note that while the baseline assumes no new policies for the environmental issues addressed in the Outlook, it does include energy policies as included in the reference (current policies) energy projections of the IEA (2009a,b, 2010a) and the assumption that the EU Emission Trading System (EU-ETS) is implemented over the period 2006-2012, with a permit price that would rise gradually from 5 to 25 constant USD by 2012 and is not extended thereafter. ${ }^{1}$

\section{The Conditional convergence methodology}

Baseline economic scenarios underlying global environmental economic projections - such as those developed for the Intergovernmental Panel on Climate Change (IPCC) - typically assume that there will be some gradual convergence of income levels towards those of most developed economies. A similar approach is taken here, but special emphasis is put on integrating some of the current theoretical and empirical knowledge on long-term economic growth, and making transparent assumptions about the drivers of GDP growth over the projection period (for discussion of assumptions, detailed results and data sources, see Duval and De la Maisonneuve, 2010).

The "conditional convergence" hypothesis is incorporated into the projections. GDP per capita is first decomposed as follows:

$$
Y_{t} / \operatorname{Pop}_{t}=\left(K_{t} / Y_{t}\right)^{\alpha /(1-\alpha)} A_{t} h_{t}\left(L_{t} / \operatorname{Pop}_{t}\right)
$$

where $Y_{t} / P_{p} p_{t}, K_{t} / Y_{t}, A_{t}, h_{t}$, and $L_{t} / P_{o p}$ denote the level of GDP per capita (using PPP exchange rates to convert national GDPs into a common currency), the capital/output ratio, total factor productivity (TFP), human capital per worker and the employment rate, respectively; $\alpha$ is the capital share in aggregate output.

\footnotetext{
${ }^{1}$ Note that all policy simulations carried out for the Environmental Outlook will assume continuation of the EU-ETS until 2020. This way, the costs of the policies are explicitly represented for in the simulations.
} 
Based on this, long-term projections are then made for each of the four components so as to project the future path of GDP per capita:

- Long-term annual TFP growth at the "frontier", i.e. for best performers, defined here as the average of the "high-TFP" OECD countries, is $1.5 \%$. The other countries converge to that frontier gradually.

- In countries where it is currently highest, the human capital of the 25-29 age group is assumed to level off, based on historical trends. The speed at which other countries converge to that frontier is assumed to tend gradually towards a world average between 1960 and 2000. The human capital of the working-age population is then projected by age cohorts.

- Capital/output ratios in all countries gradually converge to the level of the United States,

- Employment projections combine population, age structure, participation and unemployment scenarios and correspond to the 2008 revision of the United Nations medium population projections. In those OECD countries where participation is currently highest, future retirement ages are partially indexed to life expectancy. Elsewhere, participation rates gradually converge to the average level in "frontier" countries. Unemployment rates converge slowly to their structural level.

This framework was applied to 76 countries, covering around $90 \%$ of the current global GDP and population. ${ }^{2}$ For countries where energy resources comprise a large part of GDP, the above methodology is adapted and GDP projections are made using long-term projections for energy prices and energy demand (which in turn are influenced by the GDP projections of the other countries).

This approach, which has also been used for OECD (2009), addresses recent criticisms of economic projections using market exchange rates, which form the vast majority of scenarios in the literature. This is achieved in two ways: (i) By using purchasing power parities (PPPs), not market exchange rates, to compare initial income per capita levels; (ii) by assuming faster future productivity growth in tradable than in non-tradable industries, in line with historical patterns. The real exchange rate of fast-growing countries typically appreciates, thus reflecting the "Baumol-Balassa-Samuelson" effect. Therefore, the growth path for GDP per worker, expressed in PPP terms, as produced by the ENV-Linkages model combines both a volume effect (GDP growth in constant national currency) and a relative price effect (the real exchange rate appreciation), with the former being the main driver of GHG emissions.

\section{Key trends and drivers of economic growth}

\subsection{Labour market drivers}

As discussed above, labour supply is a key determinant of economic growth: whereas capital inputs to production can be increased through increased expenditures on investments, labour inputs are largely restricted by the amount of people available on the labour market. The most prominent driver of changes in employment is population. Figure 1 shows the trend in regional population as projected by the UN (2009).

2 For all remaining countries, the productivity convergence scenario to labour productivity or GDP per capita was applied instead of TFP. 
Figure 1. Trend in population by region, mln. persons

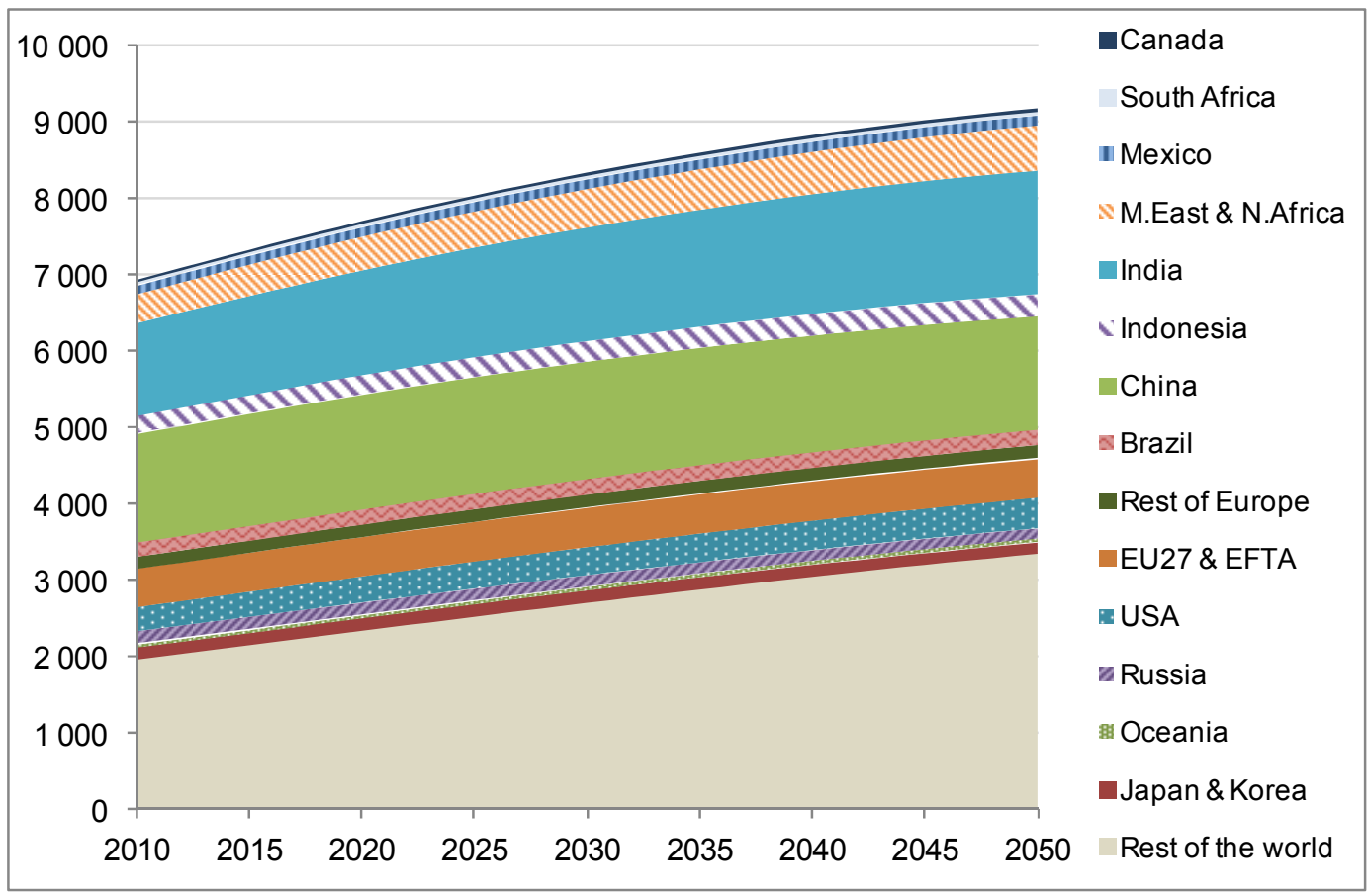

The average annual growth rate of population is compared to that of employment in Figure 2. It illustrates that while population and employment are correlated, even over a long time horizon employment dynamics differ from population dynamics.

\section{Figure 2. Average annual growth rates of population and employment for the period 2010-2050, in percentage}

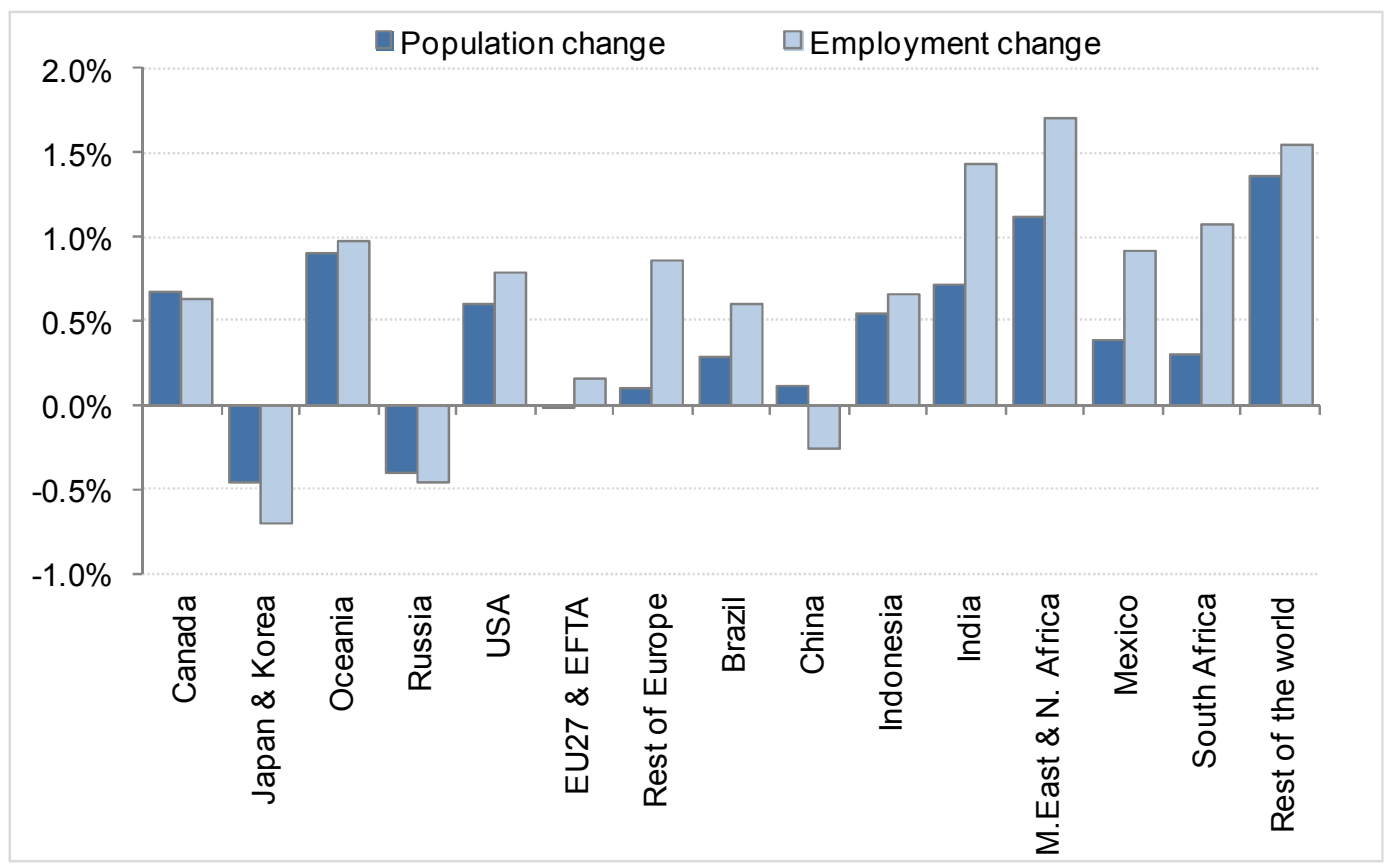


Figure 3 shows how population changes interact with other drivers of employment to fuel employment growth. The decomposition analysis presented in Figure 3 is based on a simple accounting rule:

$$
\text { Employment }=\text { Population } \cdot \frac{\text { AdultPopulation }}{\text { Population }} \cdot \frac{\text { ActivePopulation }}{\text { AdultPopulation }} \cdot \frac{\text { ActivePopulation-Unemployment }}{\text { ActivePopulation }}
$$

The multiplication in levels implies that the growth rate of employment is the sum of the growth rates of its constituent parts. The figure shows average growth determinants for the period 2010-2015 (panel A), 2015-2030 (panel B) and 2030-2050 (panel C), respectively. In the short run (2010-2015), population changes are the main driver of employment growth in most regions, while the current economic recovery also implies opportunities for reduced unemployment in the OECD regions. In the medium term (2015-2030) reductions in unemployment levels are projected to boost employment in non-OECD regions, as these regions start to gradually converge from their current short-term growth rates to a more balanced long-term growth. Average participation rates are progressively reduced, among others due to the increasing number of retired people in the higher age cohorts. In turn, overall rates of employment growth slowdown in more and more regions. It should be noticed that the change in participation rate is also indirectly linked to changes in population structure, as for example a rapidly aging population (as projected in some regions between 2015 and 2030, such as Japan and China) will reduce both the active population as well as the average rate of participation. In the long run, employment growth rates tend to become smaller, with in most regions offsetting contributions from the different drivers.

Figure 3. Decomposition of the drivers of employment changes by region, in percentage

Panel A: Average annual growth rates for the period $2010-2015$

$\left.\begin{array}{l}3.0 \% \\ 2.5 \% \\ 2.0 \% \\ 1.5 \% \\ 1.0 \% \\ 0.5 \% \\ 0.0 \% \\ -0.5 \% \\ -1.0 \%\end{array}\right]$


Panel B: Average annual growth rates for the period $2015-2030$

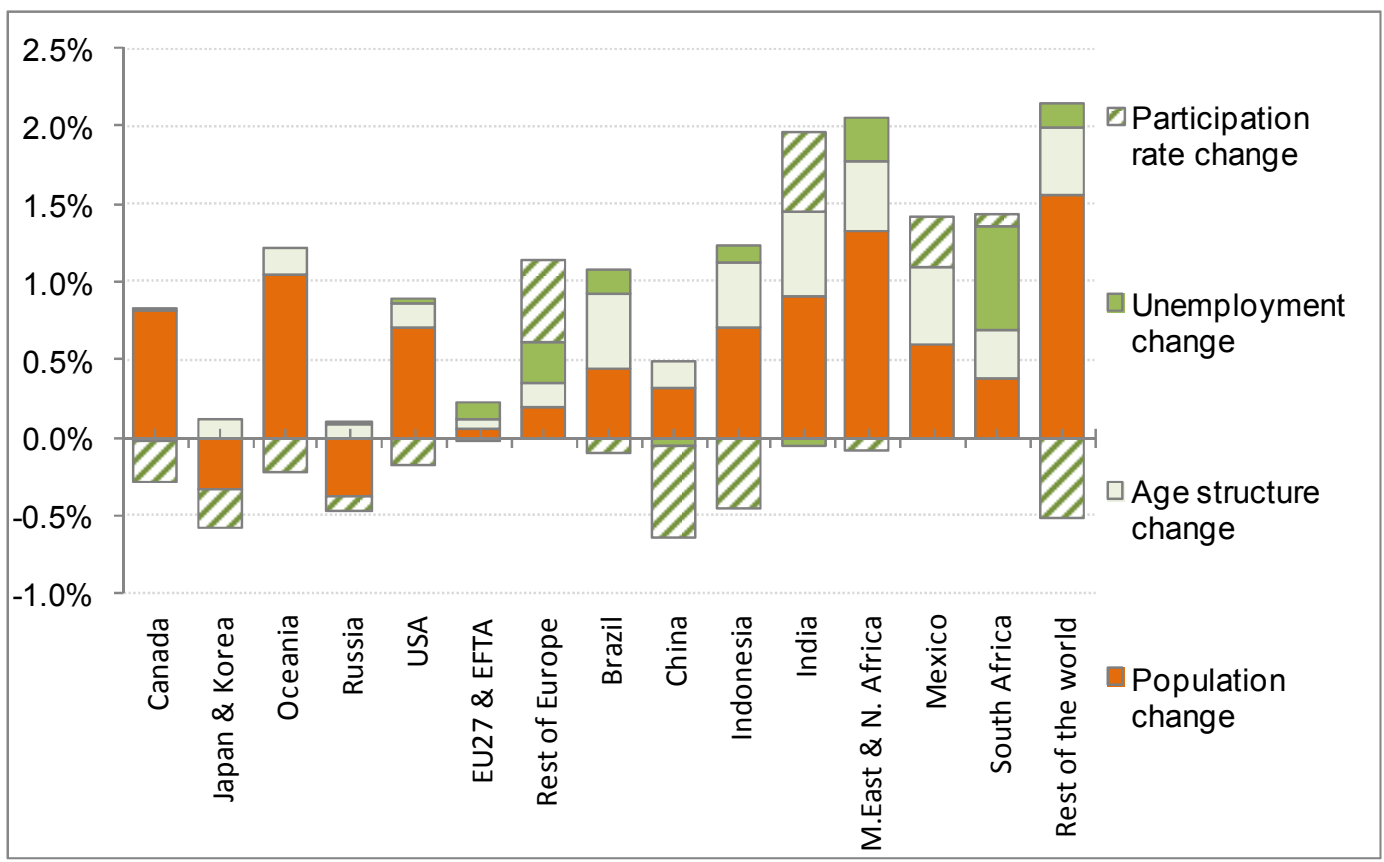

Panel C: Average annual growth rates for the period $2030-2050$

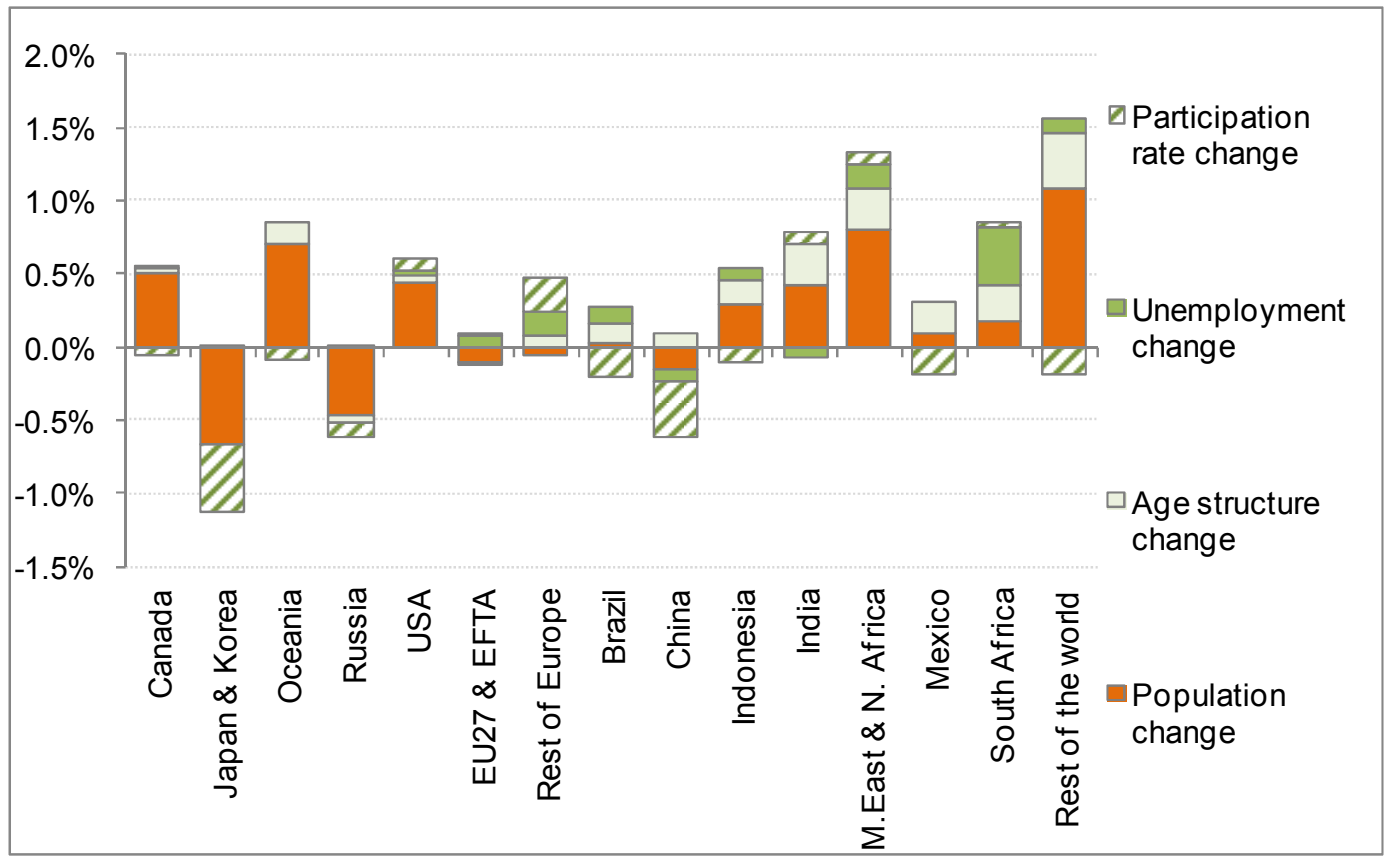


The resulting employment levels in the different regions are summarised in Table 3 for 2015, 2030 and 2050, respectively.

Table 3. Employment by region for specific periods, in $\mathrm{mln}$. persons

\begin{tabular}{|lr|r|r|}
\hline & \multicolumn{1}{|c|}{$\mathbf{2 0 1 5}$} & \multicolumn{1}{c|}{$\mathbf{2 0 3 0}$} & \multicolumn{1}{c|}{$\mathbf{2 0 5 0}$} \\
\hline Canada & 18 & 20 & 22 \\
\hline Japan \& Korea & 88 & 82 & 65 \\
Oceania & 19 & 22 & 25 \\
Russia & 78 & 74 & 65 \\
USA & 152 & 169 & 191 \\
EU27 \& EFTA & 231 & 239 & 237 \\
Rest of Europe & 59 & 70 & 77 \\
Brazil & 99 & 115 & 117 \\
China & 816 & 798 & 720 \\
Indonesia & 111 & 125 & 137 \\
India & 590 & 786 & 906 \\
M.East \& N.Africa & 153 & 206 & 268 \\
Mexico & 50 & 62 & 64 \\
South Africa & 17 & 21 & 25 \\
Rest of the world & 861 & 1,097 & 1,446 \\
\hline World & 3,342 & 3,885 & 4,365 \\
\hline
\end{tabular}

\subsection{Capital market drivers}

On a balanced growth path, the rate of growth of capital would keep up with the growth in employment and investment levels would adjust to reflect changes in the labour market. In reality, however, economies are not on a balanced growth path. Especially in developing countries capital is still relatively scarce compared to labour, and thus high investment levels are warranted to stimulate growth. Over time, as these countries converge to their "frontier", investment levels will tend decrease over time.

Figure 4 largely confirms this trend. The exceptions are for those cases where strong demographic effects lead to increases in active population over time, and investment levels keep increasing to match capital growth rates with labour growth rates. 
Figure 4. Trend in gross capital investments by region, in percentage of GDP



Figure 5 illustrates how the convergence process is implemented in the baseline: in the short run, public savings rates differ widely across regions, and fluctuate over time (not least due to the economic crisis). In the longer run, however, they are assumed to all gradually diminish such that by the end of the model horizon, in 2050, government budgets are balanced.

Figure 5. Trend in public savings by region, in percentage of GDP

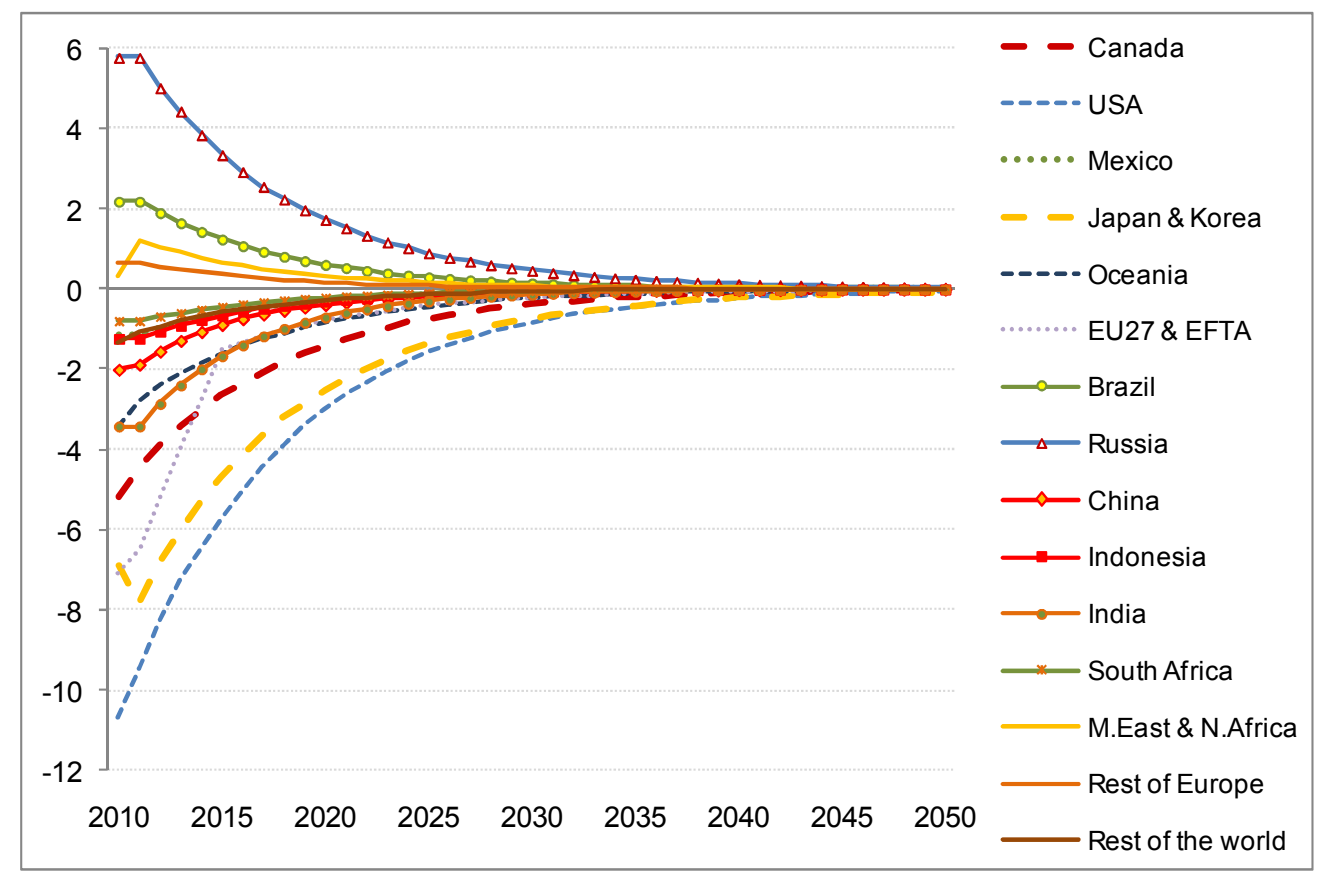


Figure 6 presents the last piece of the savings-investment drivers of capital growth: trends in savings by private households, in percentage of disposable income. This trend essentially follows from the assumptions on the other drivers, to ensure that there is equality between savings and investments, net of the capital balance.

Figure 6. Trend in private savings by region, in percentage of household disposable income

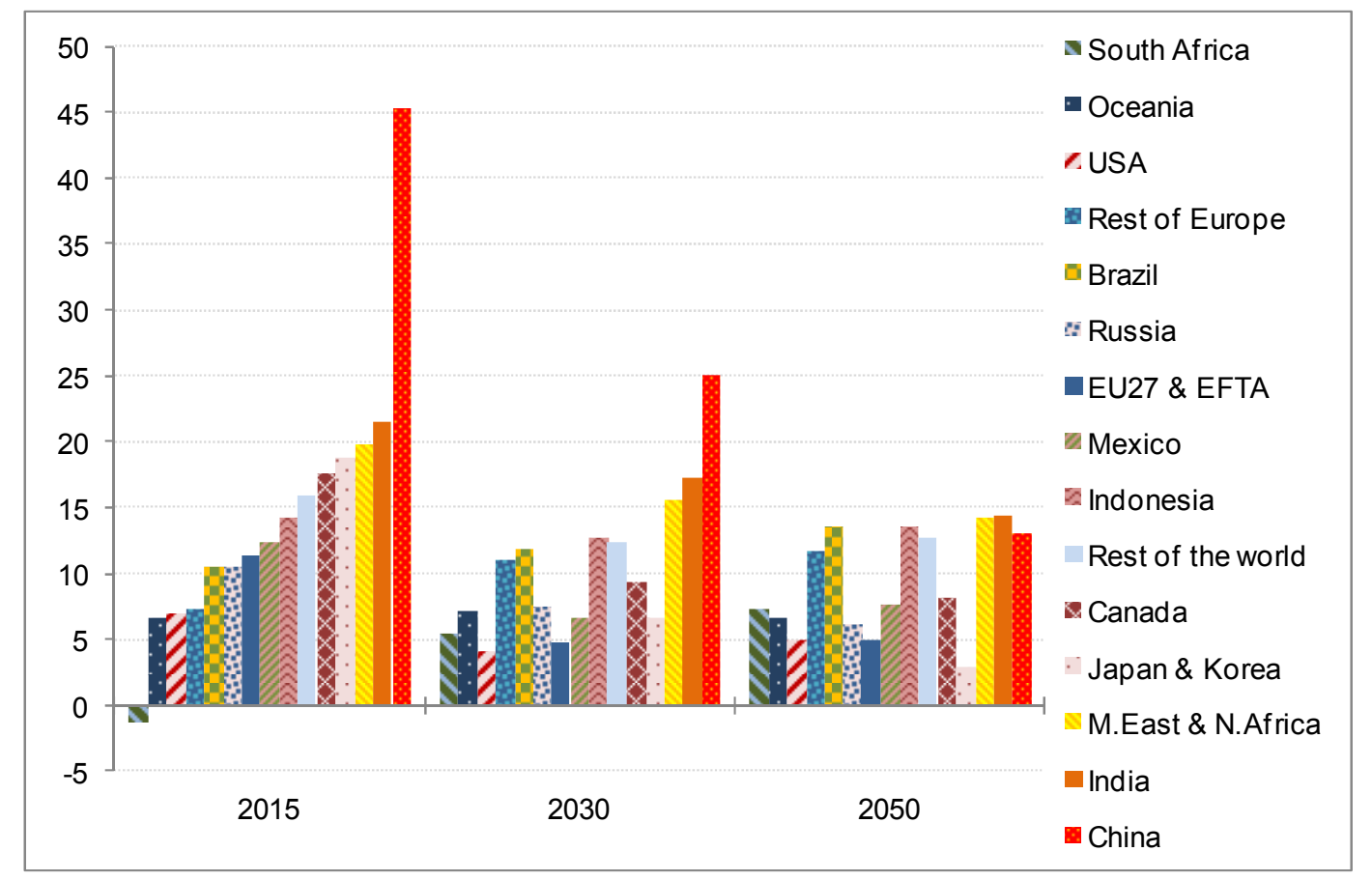

\subsection{International drivers}

International trade has in the past proven to be a major engine of growth. The expectation in this economic baseline is that international trade will continue to grow at a pace that is greater than GDP growth. But the existing imbalances on the current account seem untenable over the long run. Therefore, Figure 7 shows a gradual reduction of current account balances over time. For most regions, the current account is projected to balance by 2050 , but larger imbalances for China and the USA require a longer time period to fully fade. Figure 8 shows the accompanying trend in real exchange rates, while Figure 9 shows that of terms of trade, both indexed to 2010 levels. 
Figure 7. Trend in current account balances by region, in 2010 constant billions USD at MER3

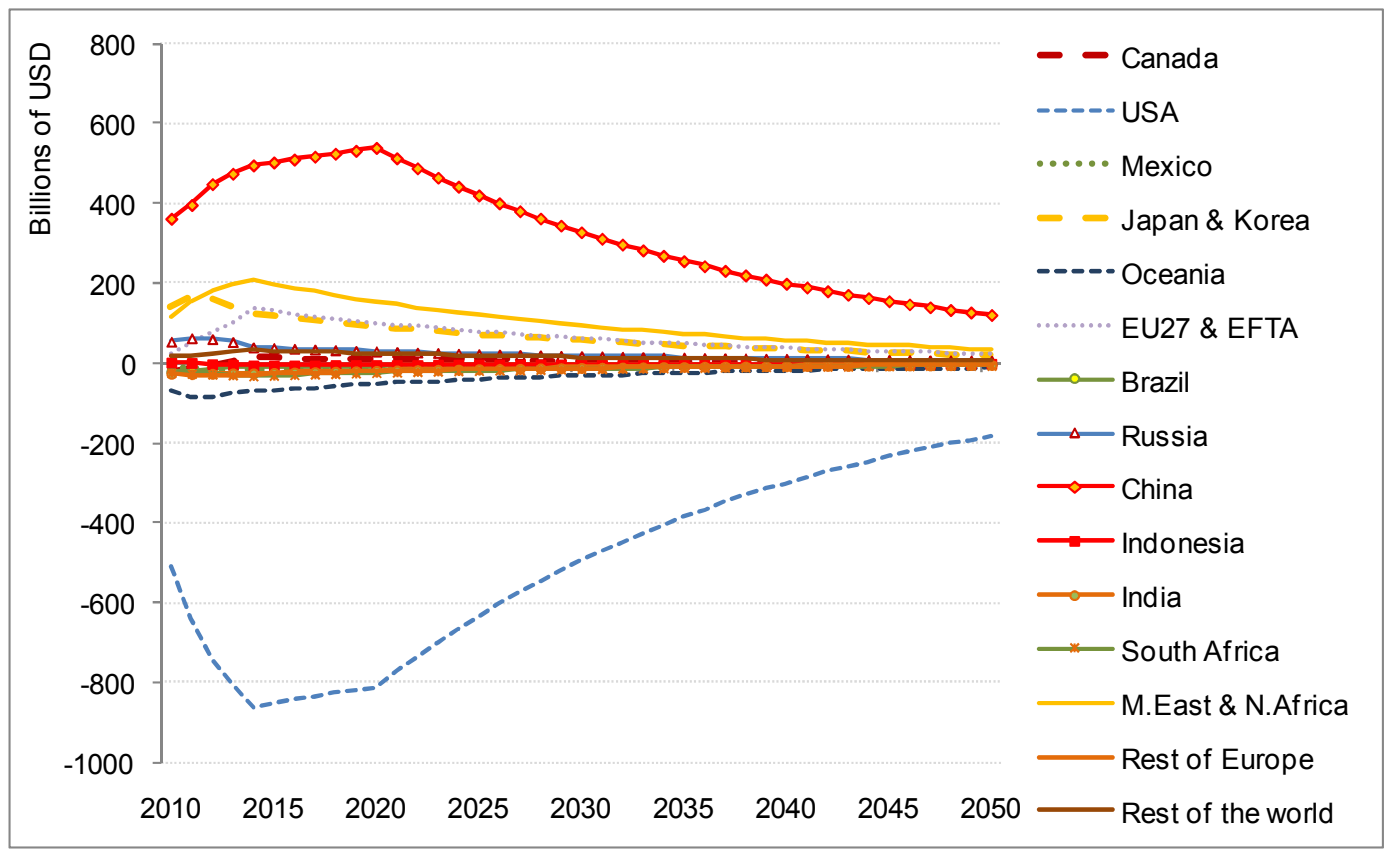

Figure 8. Trend in real exchange rates by region, indexed to 2010

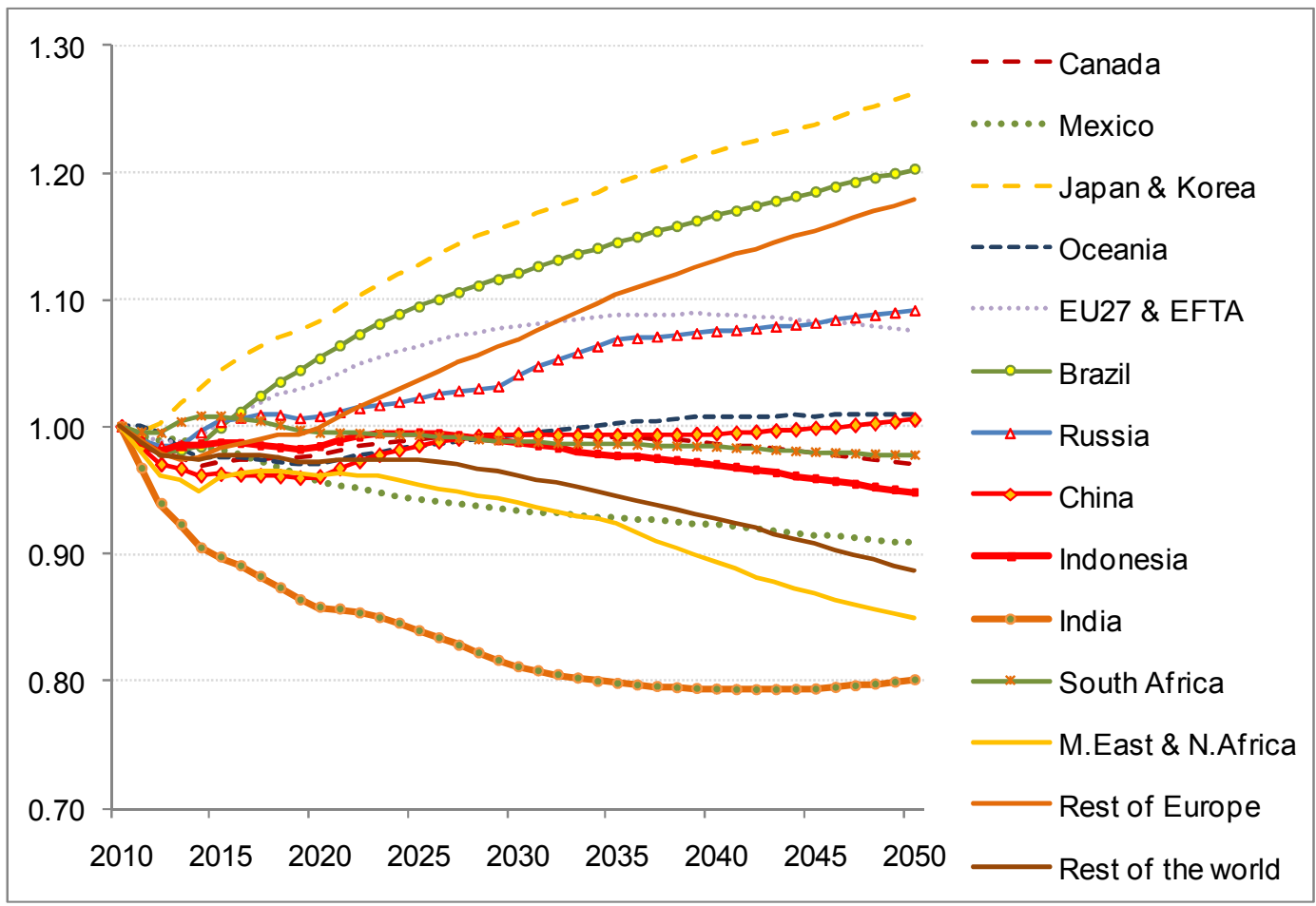

Note: Real exchange rates are defined as the change in Consumer Price Index of the region vis-à-vis USA, where all countries use the same basket of goods as weights, the US consumer budget shares.

3 All monetary values are expressed in real terms, in constant 2010 US dollars, unless otherwise indicated. 
Figure 9. Trend in terms of trade by region\#, indexed to 2010

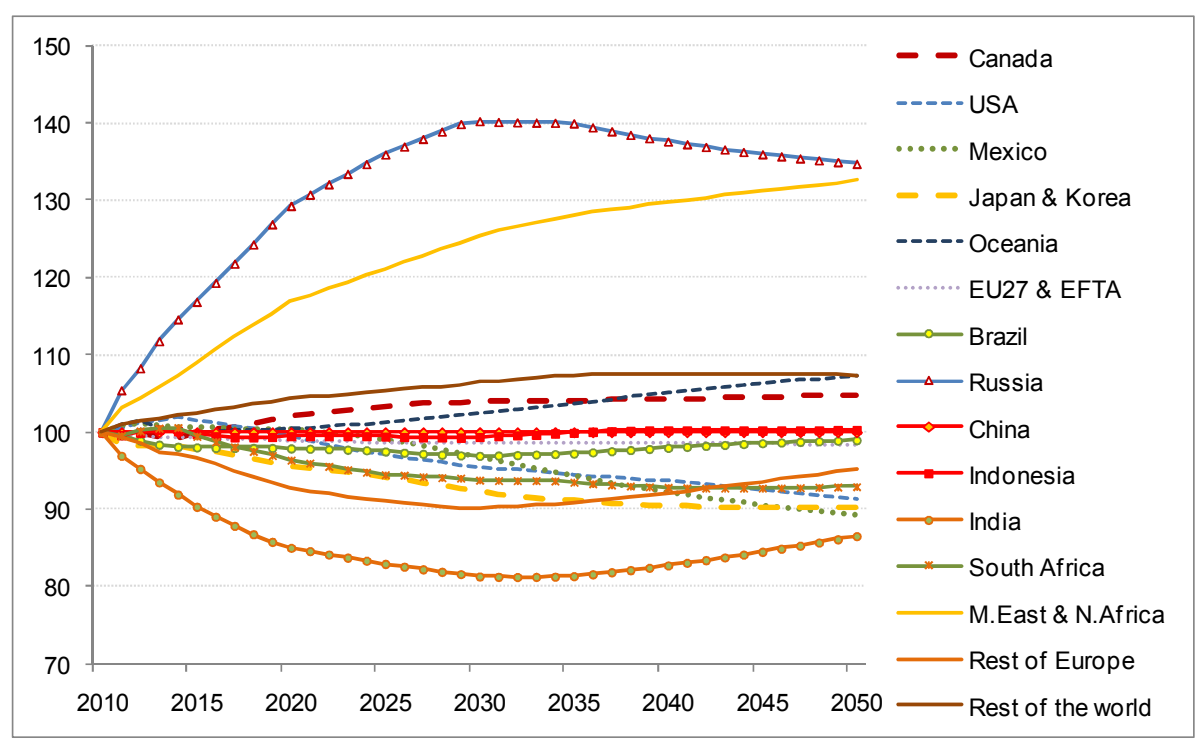

Note: Terms of trade for each country are defined as the ratio of the real price index of exports (FOB prices) to the real price index of imports (CIF prices).

\subsection{Sectoral composition of the economies}

Recent decades have observed a structural shift towards a more services oriented economy. This trend is levelling off in OECD countries, and sector shares are more or less stable over time, as shown in Figure 10. For most emerging economies and developing countries the sectoral composition of real GDP is projected to continue to evolve over the coming decades towards more services oriented economies. These trends reflects the mix of assumptions made on final demands projections (with an underlying convergence assumption of preferences with convergence of income per capita), sector specific labour productivities assumptions (see Chateau et al. 2012) and technological shifts.

Figure 10. Sectoral composition of GDP by region for specific periods, in percentage






\subsection{Resulting trends in Gross Domestic Product (GDP)}

Capital and labour supply growth fuel growth in GDP. As Figure 11 shows, global GDP is expected to nearly triple over the coming four decades in the baseline projection. The largest growth is observed in India and Africa, where a huge growth potential exists. These differences in growth rates are more easily visible in Table 4.

Figure 11. Trend in real Gross Domestic Product (GDP) valued at market prices by region, in billions USD ${ }^{4}$

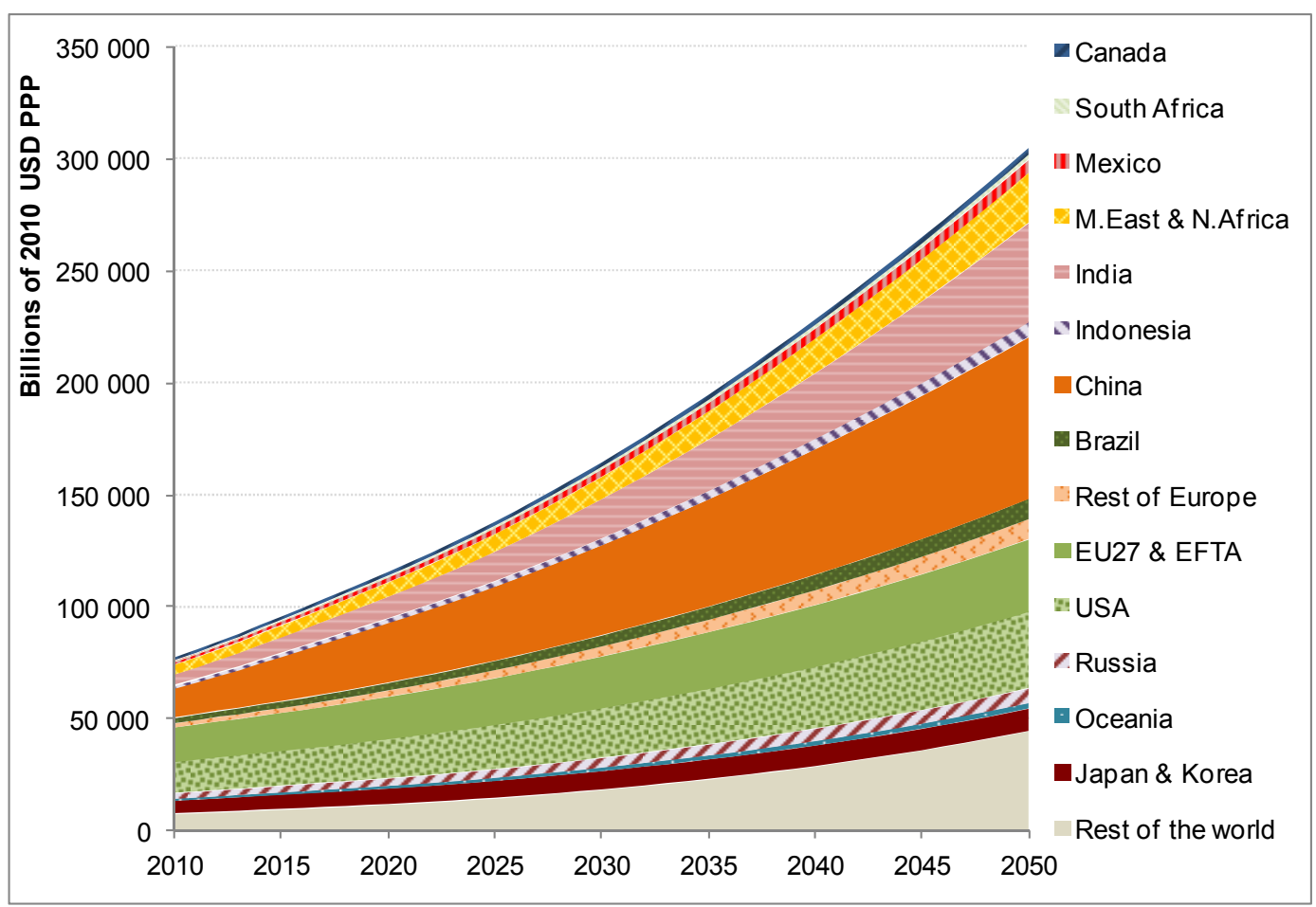

\footnotetext{
${ }^{4}$ All monetary values are expressed in real terms, in constant 2010 US dollars expressed in PPP terms, unless otherwise indicated.
} 
Table 4. Annual average real GDP growth rates, 2010-2050 Based on constant 2010 USD PPP

\begin{tabular}{lccc}
\hline & $2010-2020$ & $2020-2030$ & $2030-2050$ \\
\hline Canada & $2.5 \%$ & $2.3 \%$ & $2.1 \%$ \\
Japan \& Korea & $2.1 \%$ & $1.6 \%$ & $1.0 \%$ \\
Oceania & $2.8 \%$ & $2.4 \%$ & $2.2 \%$ \\
Russia & $3.0 \%$ & $2.8 \%$ & $2.2 \%$ \\
USA & $2.2 \%$ & $2.3 \%$ & $2.1 \%$ \\
EU27 \& EFTA & $2.1 \%$ & $2.0 \%$ & $1.7 \%$ \\
Rest of Europe & $4.7 \%$ & $5.0 \%$ & $3.6 \%$ \\
Brazil & $3.7 \%$ & $4.0 \%$ & $3.2 \%$ \\
China & $7.2 \%$ & $4.2 \%$ & $3.0 \%$ \\
Indonesia & $5.0 \%$ & $4.5 \%$ & $4.2 \%$ \\
India & $7.3 \%$ & $6.2 \%$ & $4.8 \%$ \\
M.East \& N.Africa & $4.1 \%$ & $4.6 \%$ & $4.1 \%$ \\
Mexico & $4.5 \%$ & $3.6 \%$ & $2.9 \%$ \\
South Africa & $4.2 \%$ & $3.8 \%$ & $3.3 \%$ \\
Rest of the world & $4.4 \%$ & $4.5 \%$ & $4.5 \%$ \\
\hline OECD & $\mathbf{2 . 3 \%}$ & $\mathbf{2 . 2} \%$ & $1.9 \%$ \\
BRIICS & $\mathbf{6 . 4 \%}$ & $4.5 \%$ & $3.5 \%$ \\
Other countries & $\mathbf{4 . 4 \%}$ & $\mathbf{4 . 6 \%}$ & $\mathbf{4 . 3 \%}$ \\
\hline World & $4.1 \%$ & $3.6 \%$ & $3.1 \%$ \\
\hline
\end{tabular}

Figure 12 decomposes the average growth rates for the periods 2010-2015, 2015-2030 and 2030-2050, respectively. In the short run (panel A), which is heavily influenced by the economic crisis, capital reallocation has been slowing down economic growth, whereas increases in capital supply are clearly the largest source of GDP growth, followed by increases in labour supply. ${ }^{5}$ As panel B shows, in the medium run labour productivity is projected to become a more important source of growth: human capital (and thus labour productivity) is projected to increase substantially over the time period 2015-2030, thereby boosting overall GDP growth rates. This transition from growth primary driven by capital inputs to a more balanced growth of capital and labour inputs continues into the 2030-2050 period (see panel C). As time passes and economies grow, a comparison of panels $\mathrm{A}$ and $\mathrm{C}$ indicates that progressively the share of capital accumulation and the share of efficient labour growth (i.e. share of human capital plus the share of employment growth) will tend to be the same. This reflects the convergence process to a balanced growth path: where all economic variables in real terms grow at the same pace, equals to efficient labour growth.

Even though the drivers of growth are based on conditional convergence, and economic activity does tend to grow more quickly in regions that are further from the frontier, this does not automatically imply that per capita consumption levels are converging as well. For instance, population increases will boost employment and hence economic activity, but may put per capita consumption levels under pressure. As Figure 13 shows, the USA remains the region with the largest consumption per capita, and while there is some convergence, large differences between regions are projected to remain to 2050 .

\footnotetext{
${ }^{5}$ Apart from capital and labour, land and natural resources also determine GDP growth; these two additional production factors are summarised in Figure 12 as "other factors".
} 
Figure 12. Decomposition of the drivers of GDP growth by region, in percentage

Panel A: Average annual growth rates for the period $2010-2015$

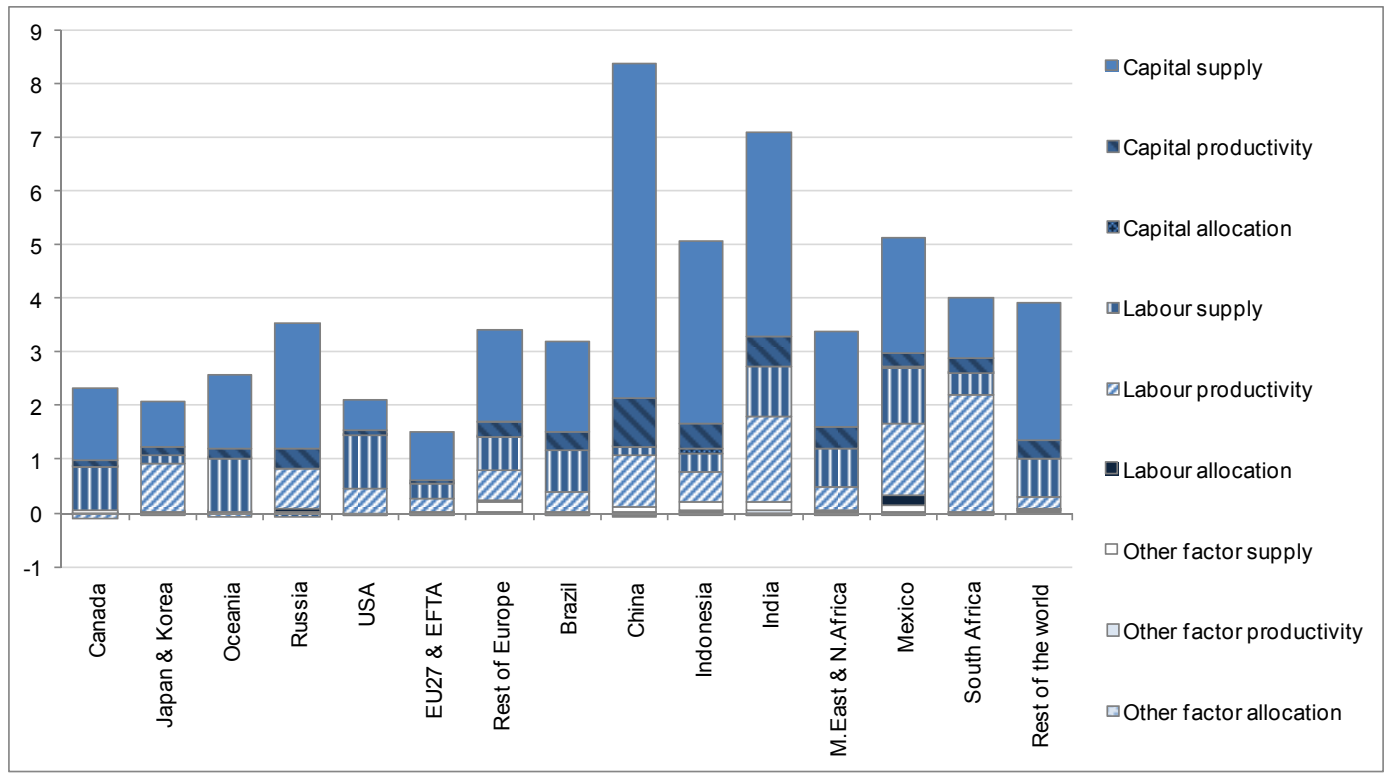

Panel B: Average annual growth rates for the period $2015-2030$

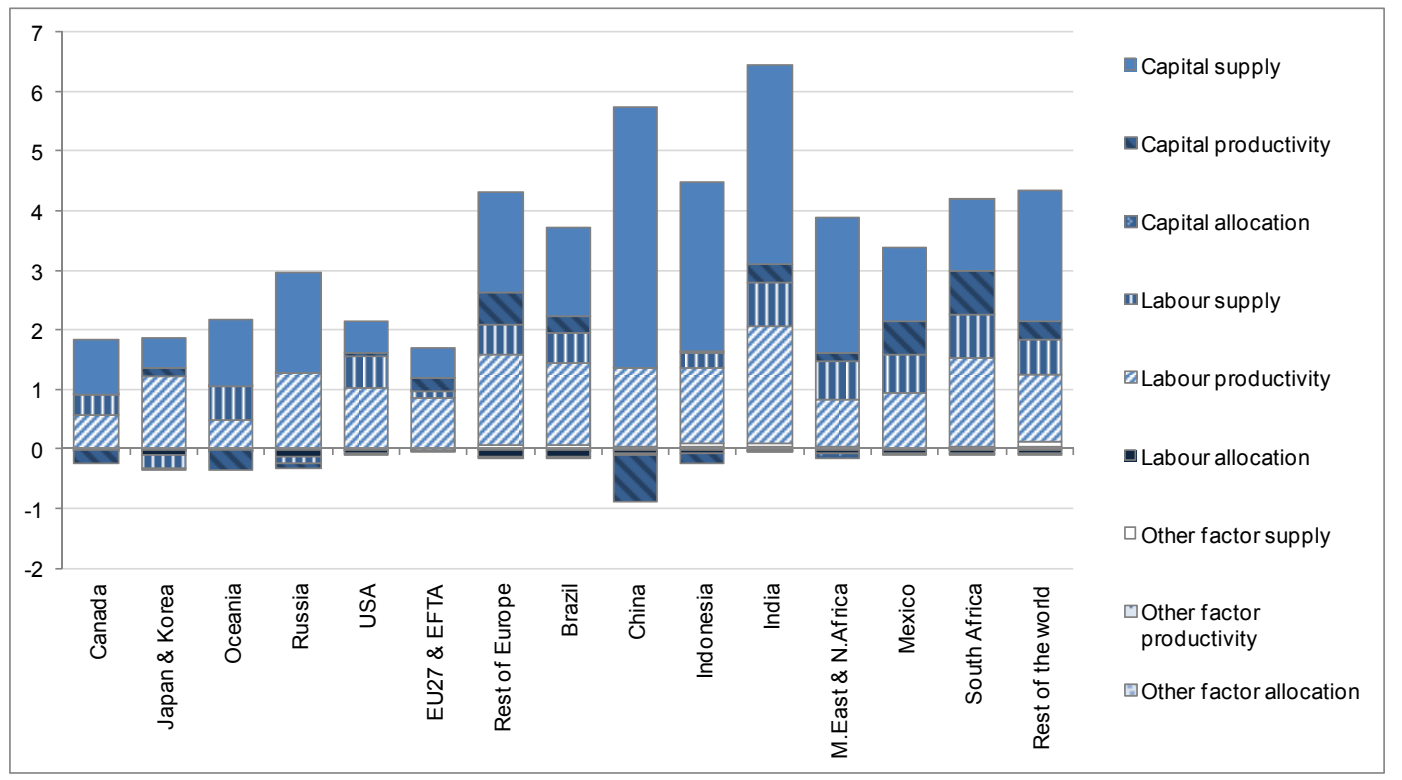


Panel C: Average annual growth rates for the period $2030-2050$

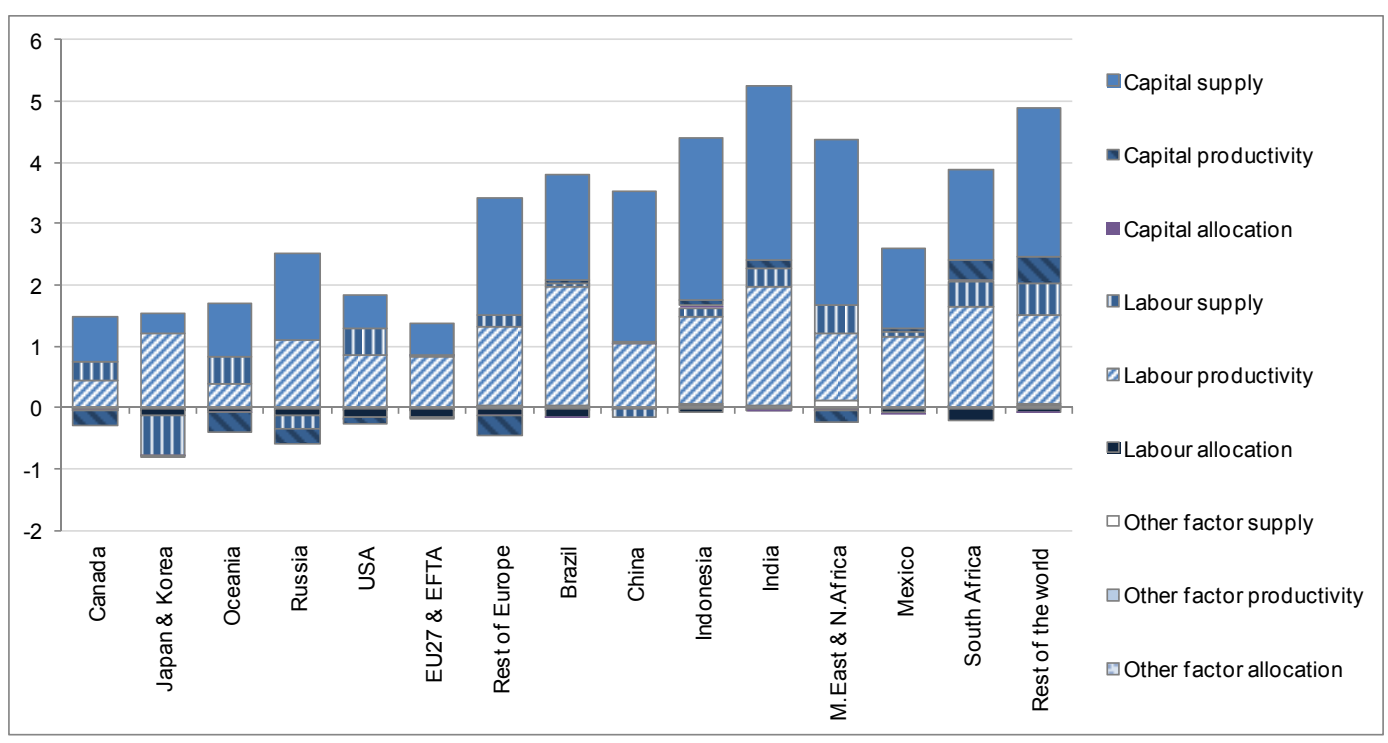

Figure 13. Per capita household consumption by region for specific periods, relative to USA (Based on constant 2010 USD PPP)

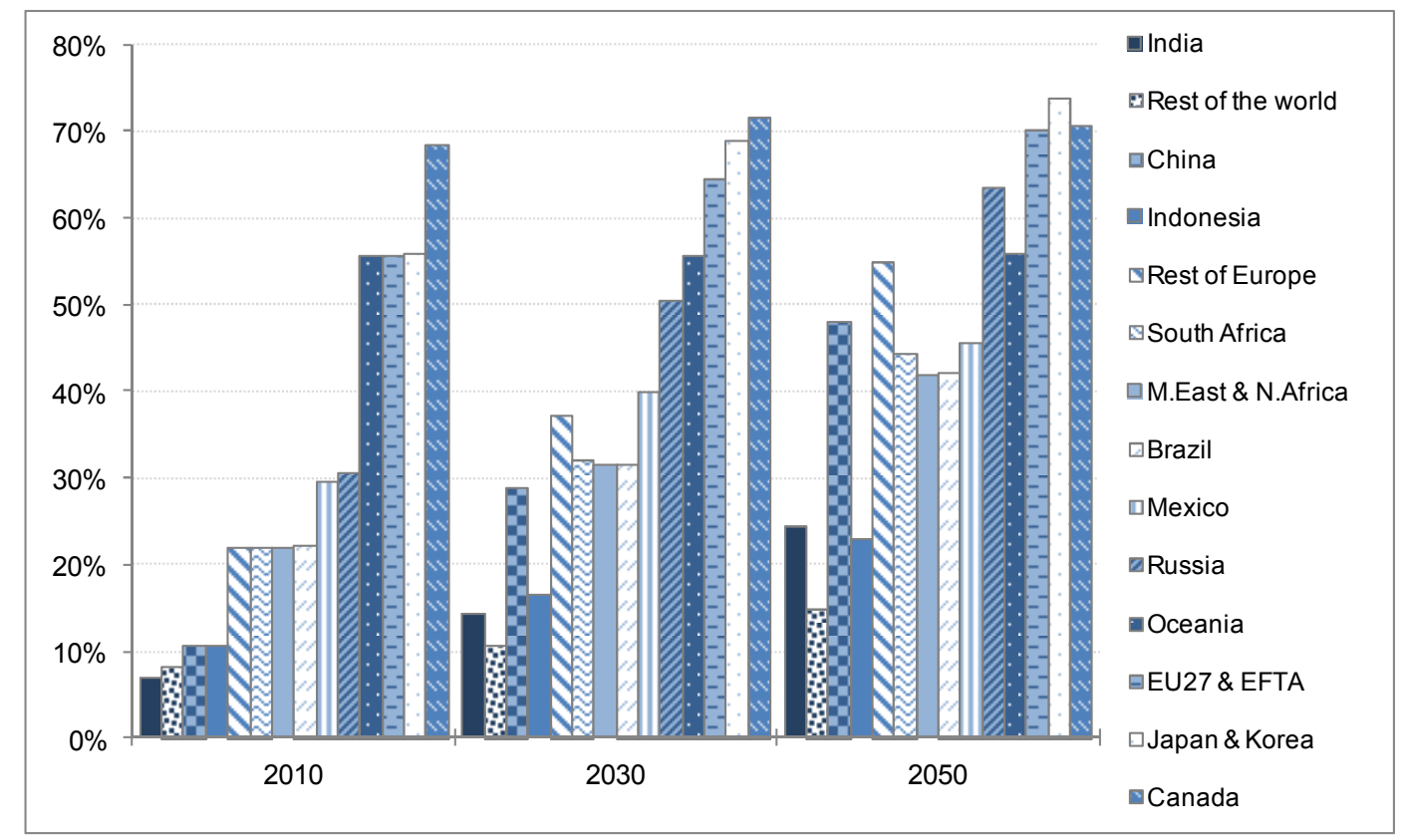

\section{Key trends and drivers of energy use and greenhouse gas emissions}

The OECD Environmental Outlook to 2050 focuses on four environmental issues: Climate change, Water, Biodiversity, and Health \& Environment. For each of these, the modelling analysis is based on integrated environmental economic baseline projections for ENV-Linkages and the IMAGE suite of models. These integrated baseline projections build directly upon the economic baseline projections described above. To illustrate how the economic baseline is augmented by additional drivers to create projections for key environmental pressures, some results for the ENV-Linkages baseline projection are 
presented here, focusing on energy use and greenhouse gas emissions. A more detailed discussion of the environmental economic baselines is reported in the OECD Environmental Outlook to 2050 (OECD, 2012).

\subsection{Additional drivers of energy use}

Increases in energy use and GHG emissions are also driven by growth in economic activity, but there are a number of additional drivers, such as energy efficiency improvements, that imply that growth rates of energy use and emissions do not exactly match with GDP growth rates. Typically, in a baseline projection without climate change policy, growth rates for emissions tend to be smaller than those of GDP, but still positive, a situation referred to as relative decoupling. Although energy prices are endogenous in the ENVLinkages model, fossil-fuel energy supplies are calibrated in the baseline to project global prices of fossil fuels to match projections made by the International Energy Agency (IEA, 2010a). Figure 14 illustrates the resulting trend of international fuel prices (based on Cost, Insurance and Freight prices); clearly, long term prices are expected to increase substantially over time, even without any upward pressure caused by climate change policies. Figure 15 shows the relative decoupling of fossil fuel energy use from economic activity: for most regions, total fossil fuel energy use per unit of GDP is roughly halved over the period 2010-2050 and continues decreasing throughout the model horizon. For Brazil, there is a short period where energy intensity does not improve; this occurs when Brazil is projected to reach its capacity for hydroenergy.

Figure 14. Trend in international prices of fossil fuels, indexed to 2010

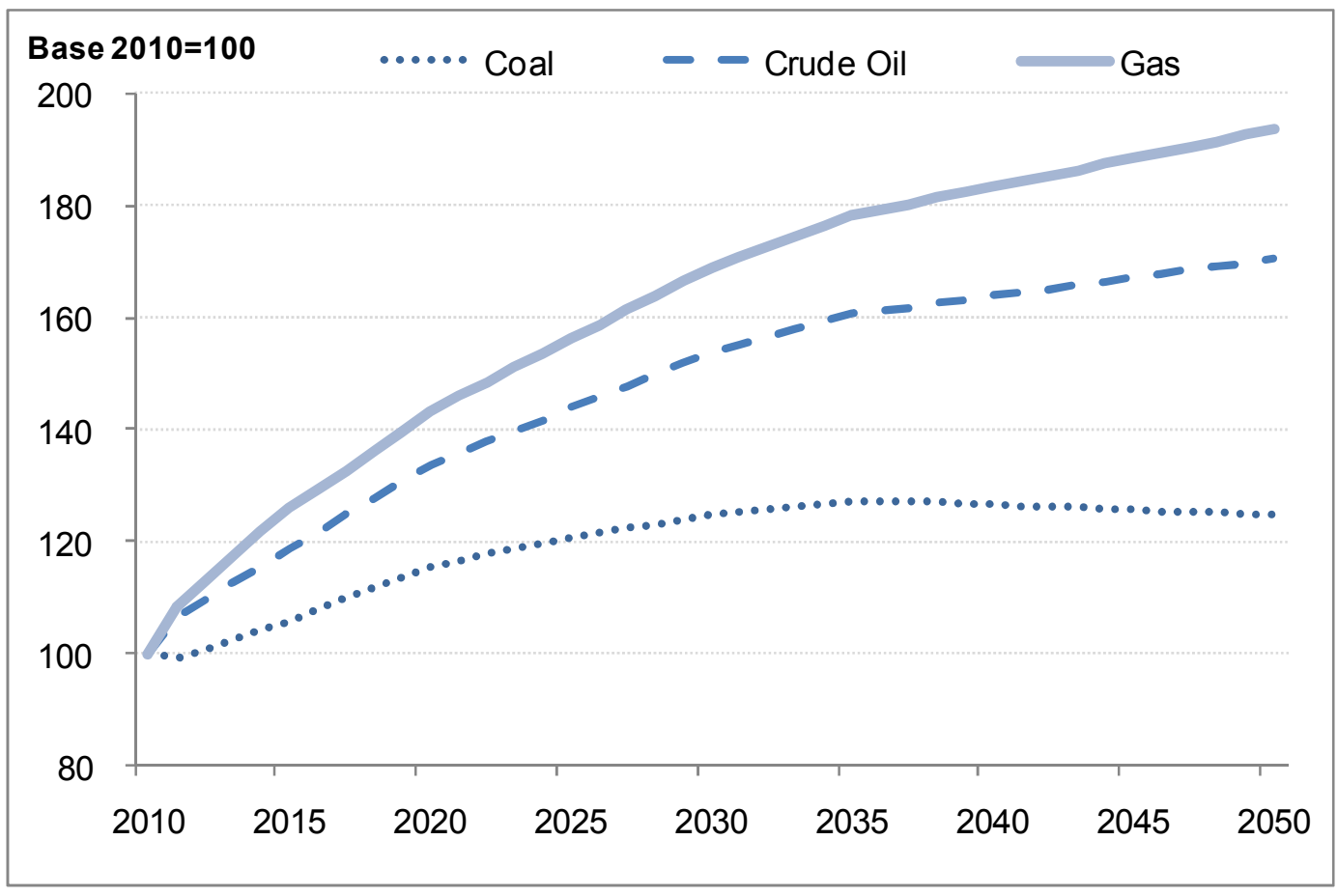


Figure 15. Trend in energy intensity by region, indexed to 2010

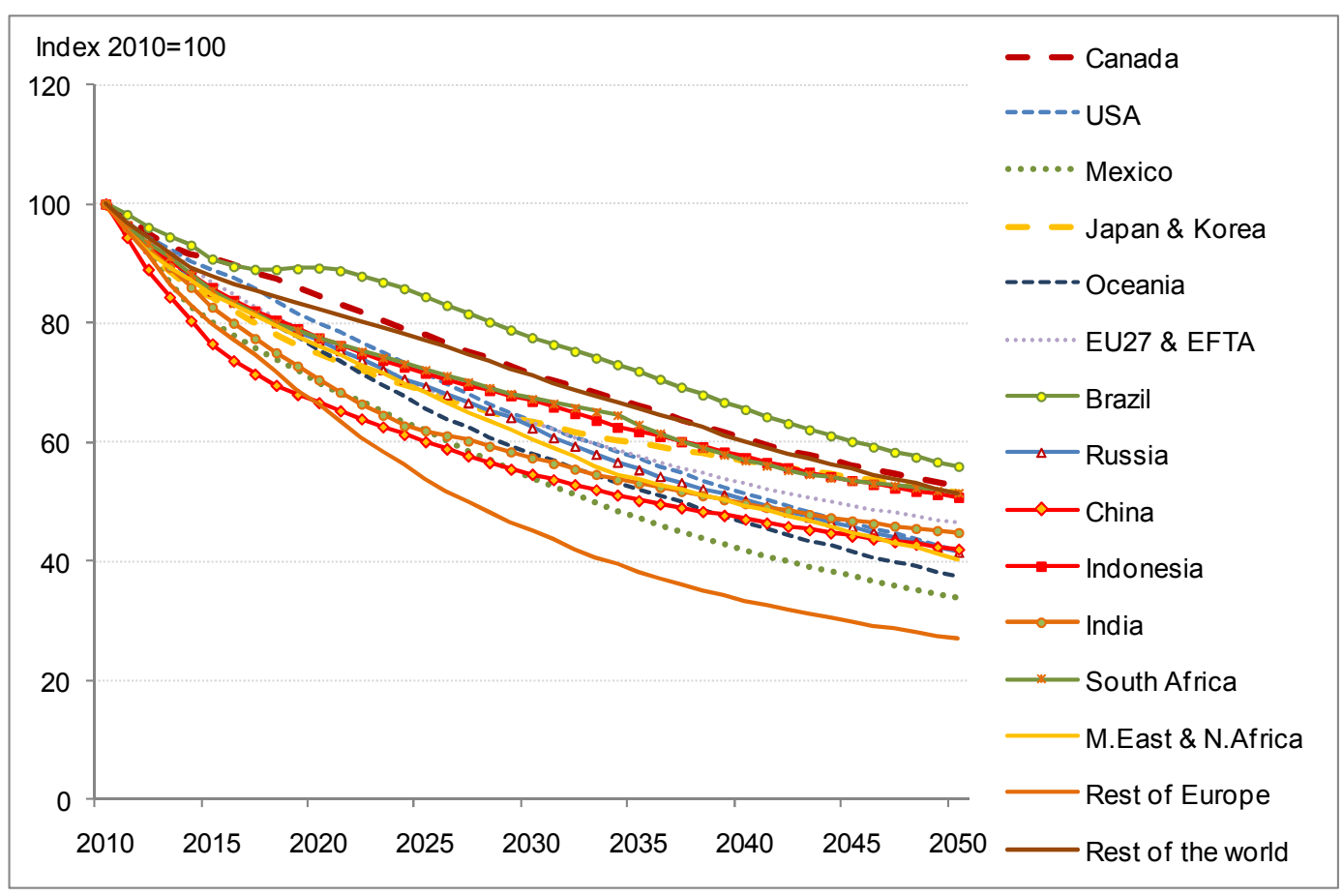

\subsection{Resulting trends in energy use and GHG emissions}

While energy efficiency improvements are widespread over the coming decades, total energy use is still projected to grow strongly to 2050. Figure 16 shows which regions are the largest producers of different types of energy. The panels illustrate that while the USA is currently a major producer of all fossil fuels, most of the growth is located in developing regions, that are projected to substantially increase their share in global production for the coming decades. Figure 17 shows what the major sources of energy for electricity production are projected to be on a global scale. It shows that while the total energy system remains heavily dependent on fossil fuels, there is a gradual shift in the electricity sector towards more renewable use, mostly hydropower. 
Figure 16. Production of fossil fuels and non-fossil fuel based electricity, by region, in Mtoe




Figure 17. Global electricity generation by source of energy, 2010, 2030 and 2050 (in GWh)


As with employment and GDP, a simple decomposition rule can be used to shed more light on the growth in energy use (total primary energy demand, to be precise) over time, see Figure 18. In this decomposition, four drivers are identified: (i) the joint effect of changes in energy intensity in different sectors; (ii) changes in sector composition of the economy, (iii) GDP per capita, and (iv) population:

$$
\text { EnergyUse }=\sum_{i}\left\{\frac{\text { EnergyUse }_{i}}{\text { ValueAdded }_{i}} \cdot \frac{\text { ValueAdded }_{i}}{G D P}\right\} \cdot \frac{G D P}{\text { Population }} \cdot \text { Population }
$$

It appears from Figure 18 that growth in GDP per capita is the main driver for increased energy use, but this is largely offset by improvements in energy intensity, especially in the energy production sectors (mainly the power sector), and by reduced shares of energy production in GDP. Exceptions are Mexico and Russia, where the energy production sectors increase its share in GDP, thereby boosting energy demand. In the long run, energy intensity improvements tend to become a more important driver of growth of total energy use.

Figure 19 illustrates the relative decoupling: global emission levels are increasing in the baseline, primarily from increased $\mathrm{CO}_{2}$ emissions from fossil fuel combustion, but in fact emissions of all gases are projected to increase, driven by the increase in economic activity. The growth rates of emissions are however much smaller than those of GDP or energy use. Finally, Figure 20 compares the resulting projection for global GHG emissions to projections from other studies. The current baseline closely follows the recent projections made by the IEA for the World Energy Outlook (IEA, 2010a; IEA, 2011) and the Energy Technology Perspectives (IEA, 2009b). These recent projections have a somewhat different profile from earlier baseline projections from ENV-Linkages (OECD, 2008; 2009). For the period until 2030, this is primarily caused by higher expected fossil fuel prices (IEA, 2009b), combined with somewhat lower GDP growth projections due to the long-term effect of the economic crisis. For the period 2030 to 2050 , the main causes of the higher growth rate of emissions in the new baseline projection are lower expected fossil fuel prices and improved calibration of energy efficiency (which led to a downward adjustment of long term energy efficiency improvement projections). Despite these differences, all these projections fall within the range presented in the latest IPCC report (IPCC, 2007), and in line with other recent projections are rather close to the upper end of the range. 
Figure 18. Decomposition of the drivers of energy use growth by region, in percentage

Panel A: Average annual growth rates for the period $2010-2030$

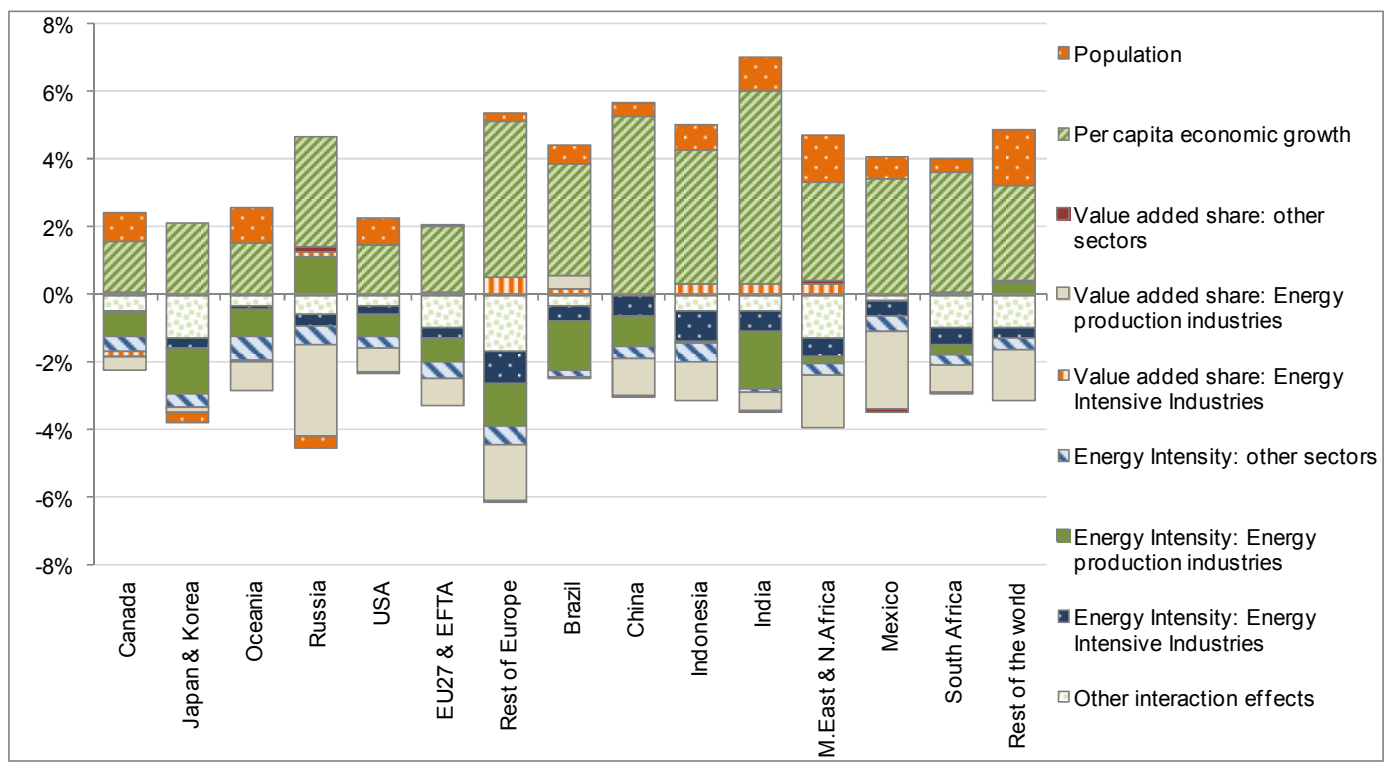

Panel B: Average annual growth rates for the period $2030-2050$

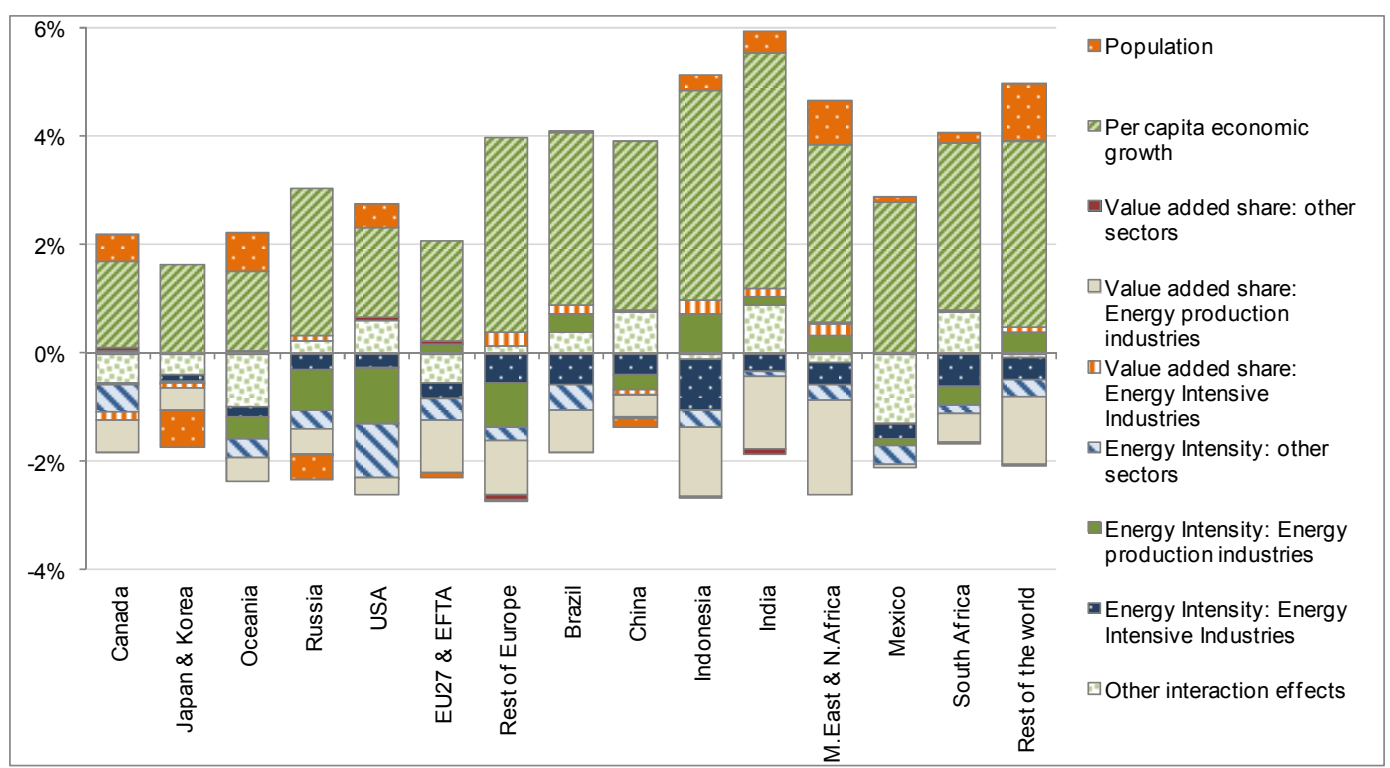


Figure 19. Trend in emissions of greenhouse gases, in MtCO2e

Panel A: emissions by gas

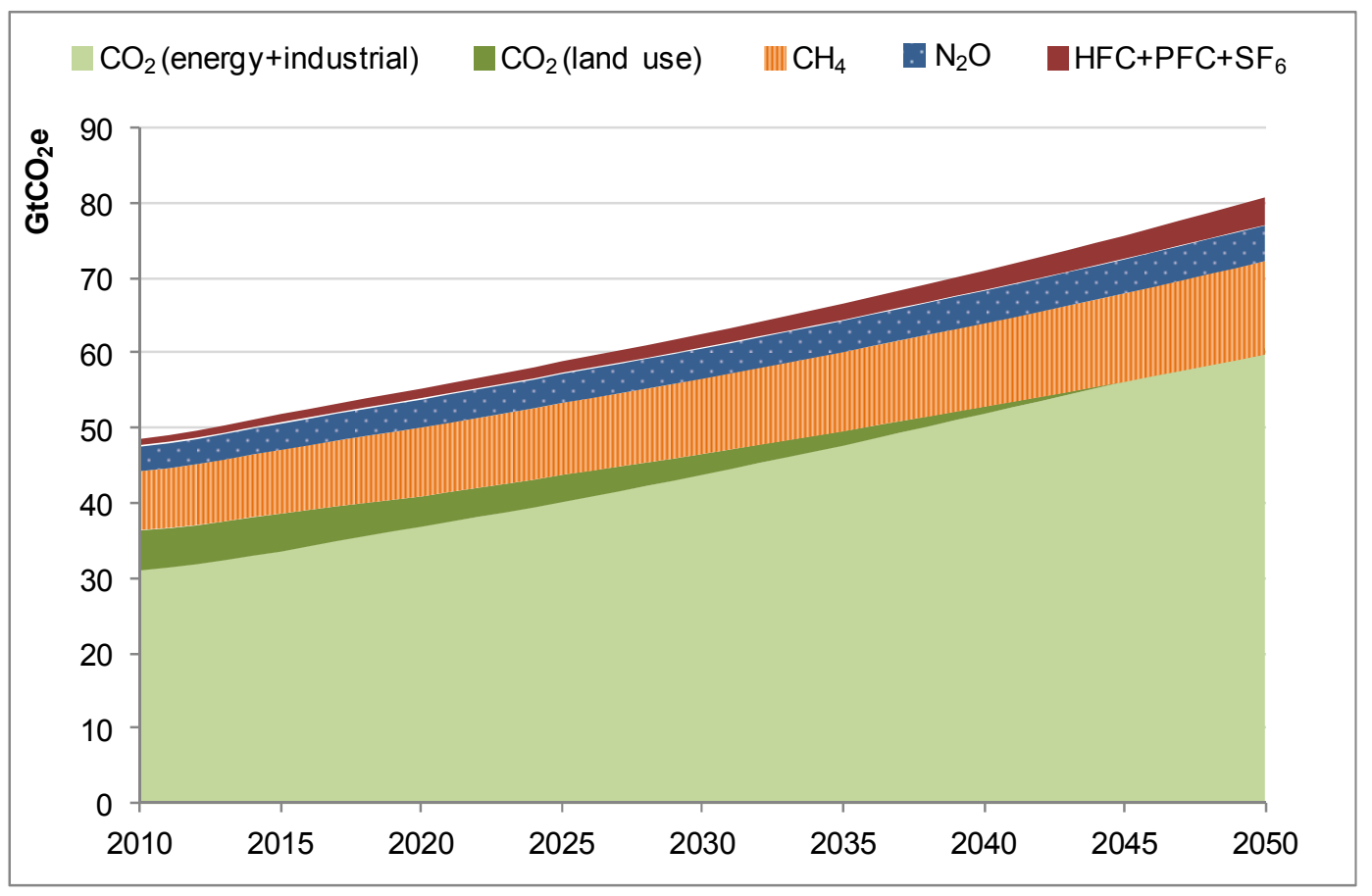

Panel B: emissions by region

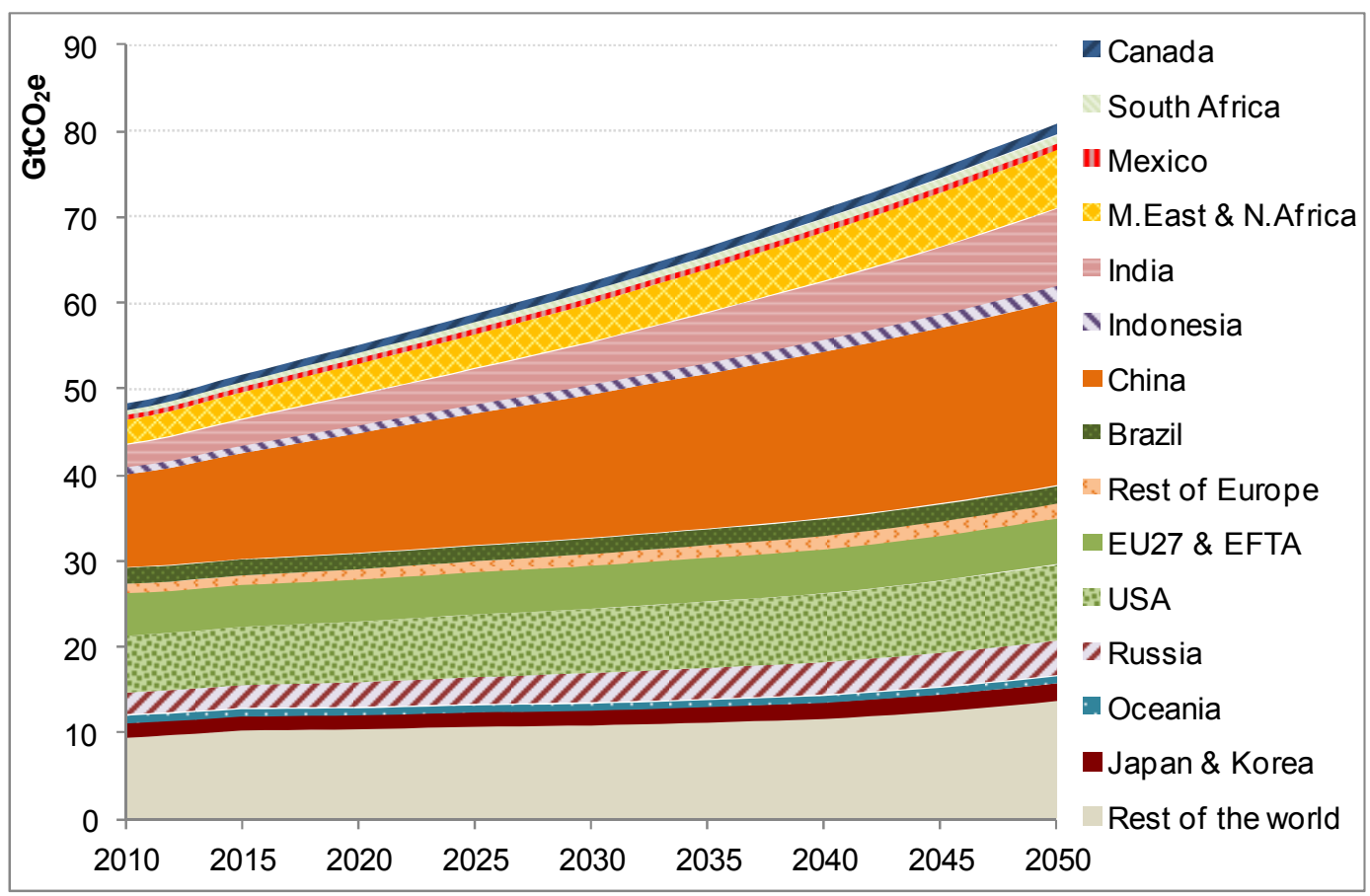


Figure 20. Comparison of global emissions of $\mathrm{CO} 2$ from fossil fuel combustion across with other studies, in MtCO2

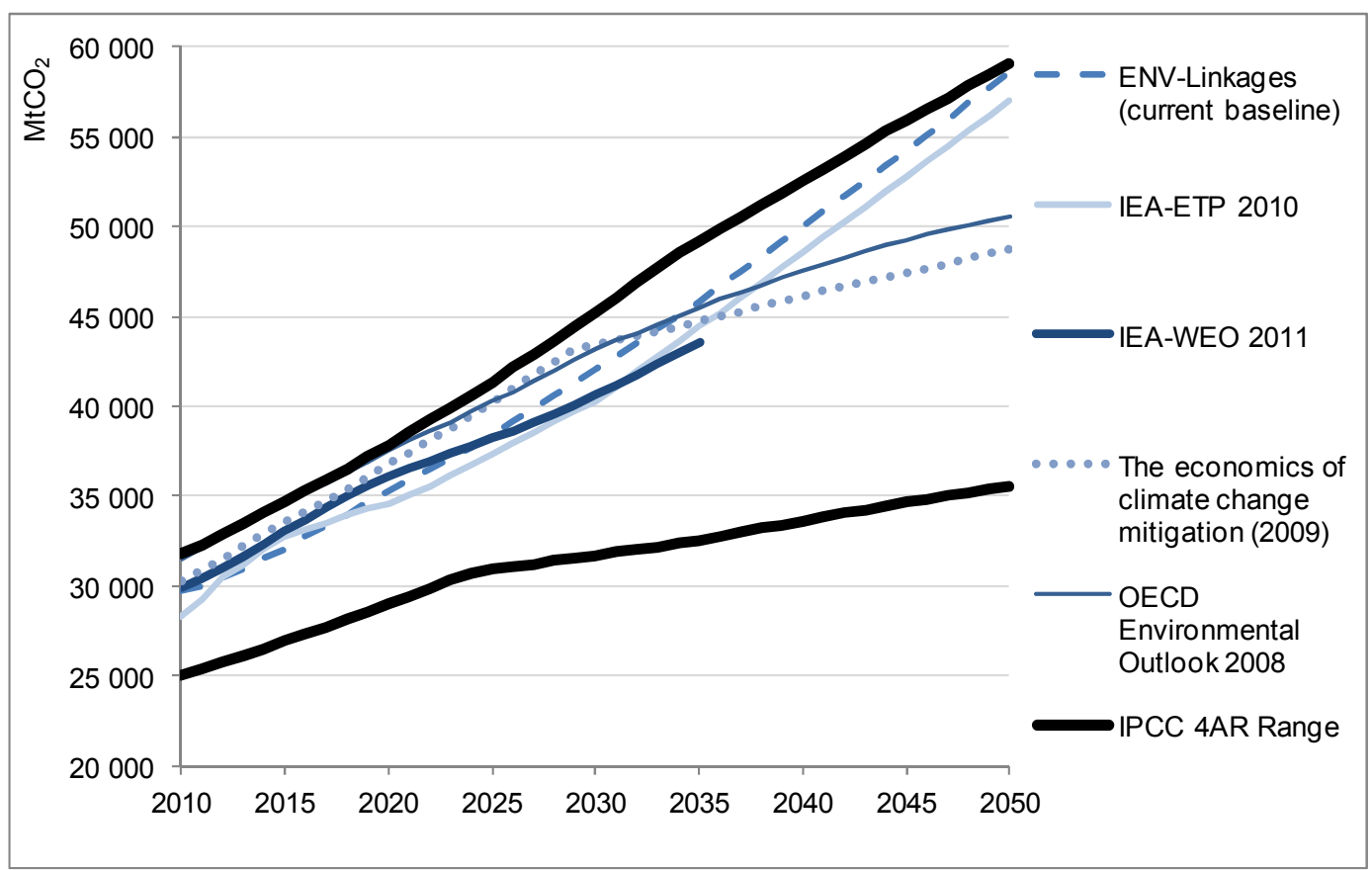




\section{REFERENCES}

Burniaux, J., Nicoletti, G., and Oliveira Martins, J., (1992), “GREEN: A Global Model for Quantifying the Costs of Policies to Curb CO2 Emissions", OECD Economic Studies, 19 (Winter).

Burniaux, J. and J. Chateau (2011), "Mitigation Potential of Removing Fossil Fuel Subsidies: A General Equilibrium Assessment", OECD Economics Department Working Papers, No. 853, OECD Publishing. doi: $10.1787 / 5 \mathrm{kgdx} 1 \mathrm{jr} 2 \mathrm{plp}$-en

Burniaux, J., J. Chateau and R. Duval (2010), "Is there a Case for Carbon-Based Border Tax Adjustment?: An Applied General Equilibrium Analysis", OECD Economics Department Working Papers, No. 794, OECD Publishing. doi: 10.1787/5kmbjhcqqk0r-en

Chateau, J., R. Dellink, E. Lanzi and B. Magné (2012), "An overview of the OECD ENV-Linkages model - version 3", OECD Environment Working paper, No. 43 (forthcoming), OECD Publishing.

Dellink, R., et al. (2010), "Towards Global Carbon Pricing: Direct and Indirect Linking of Carbon Markets", OECD Environment Working Papers, No. 20, OECD Publishing. doi: $\underline{10.1787 / 5 \mathrm{~km} 975 \mathrm{t} 0 \mathrm{cfr} 8 \text {-en }}$

Dellink, R., G. Briner and C. Clapp (2010), "Costs, Revenues, and Effectiveness of the Copenhagen Accord Emission Pledges for 2020", OECD Environment Working Papers, No. 22, OECD Publishing. doi: $10.1787 / 5 \mathrm{~km} 975 \mathrm{plmzg} 6$-en

Duval, R. and C. De la Maisonneuve (2010), A Long-Run Growth Framework and Scenarios for the World Economy, Journal of Policy Modeling 62, pp. 64-80.

GTAP (2008), 'Global Trade, Assistance, and Production: The GTAP 7 Data Base', Narayanan, B. and Walmsey, T. Editors, Center for Gloabal Trade Analysis, Dpt. of Agriculutural Economics, Purdue University.

International Energy Agency (IEA) (2009), World Energy Outlook 2009, OECD Publishing. doi: $\underline{10.1787 / \text { weo-2009-en }}$

International Energy Agency (2009b), Energy Technology Perspectives 2010: Scenarios and Strategies to 2050, OECD Publishing. doi: 10.1787/energy tech-2010-en

International Energy Agency (2010a), World Energy Outlook 2010, OECD Publishing. doi: $\underline{10.1787 / \text { weo-2010-en }}$

International Energy Agency (2010b), CO2 Emissions from Fuel Combustion 2010, OECD Publishing. doi: $\underline{10.1787 / 9789264096134-e n}$

International Energy Agency (2011), World Energy Outlook 2011, OECD Publishing. doi: 10.1787/weo-2011-en 
IEA, OPEC, OECD, World Bank (2010), "Analysis of the Scope of Energy Subsidies and Suggestions for the G-2) initiative", Joint Report prepared for submission to the G-20 Meeting of the Finance Ministers and Central Bank Governors, Busan (Korea), 5 June 2010, 26 May 2010.

IMF (2010), 'World Econonomic Outlook Database', http://www.imf.org/external/pubs/ft/weo/2010/02/weodata/index.aspx

IPCC (2007), Fourth Assessment Report of the Intergovernmental Panel on Climate Change, Cambridge University Press, New-York.

Kram, T., et al. (2012), "An overview of the IMAGE suite of models", OECD Environment Working paper, No. 44, OECD Publishing (forthcoming).

OECD (2008), OECD Environmental Outlook to 2030, OECD Publishing. doi: $10.1787 / 9789264040519$-en

OECD (2009), The Economics of Climate Change Mitigation: Policies and Options for Global Action beyond 2012, OECD Publishing. doi: 10.1787/9789264073616-en

OECD (2010), "OECD Economic Outlook No. 88", OECD Economic Outlook: Statistics and Projections (database). doi: 10.1787/data-00533-en

OECD (2012), OECD Environmental Outlook to 2050, OECD Publishing. doi: $10.1787 / 9789264122246$-en

UN (2009), World Population Prospects: The 2008 Revision, UN.

World Bank (2010), 'World Development Indicators', http://data.worldbank.org/data-catalog/worlddevelopment-indicators 


\section{ANNEX. STYLISED REPRESENTATION OF THE GENERIC PRODUCTION FUNCTION IN ENV-LINKAGES}

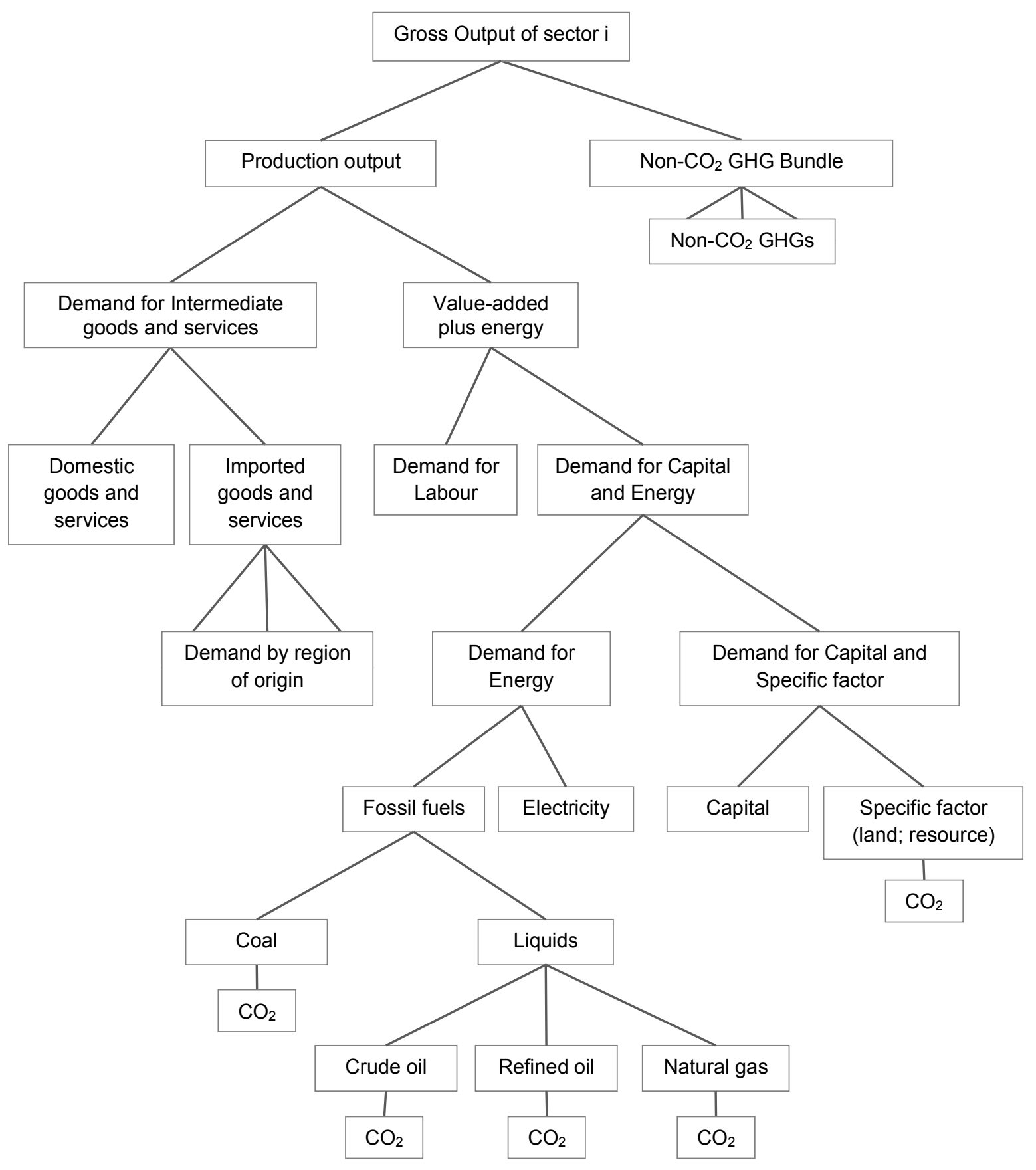

